Cochrane Database of Systematic Reviews

\title{
Topical capsaicin (low concentration) for chronic neuropathic pain in adults (Review)
}

Derry S, Moore RA

Derry S, Moore RA.

Topical capsaicin (low concentration) for chronic neuropathic pain in adults.

Cochrane Database of Systematic Reviews 2012, Issue 9. Art. No.: CD010111.

DOI: 10.1002/14651858.CD010111.

www.cochranelibrary.com 
TABLE OF CONTENTS

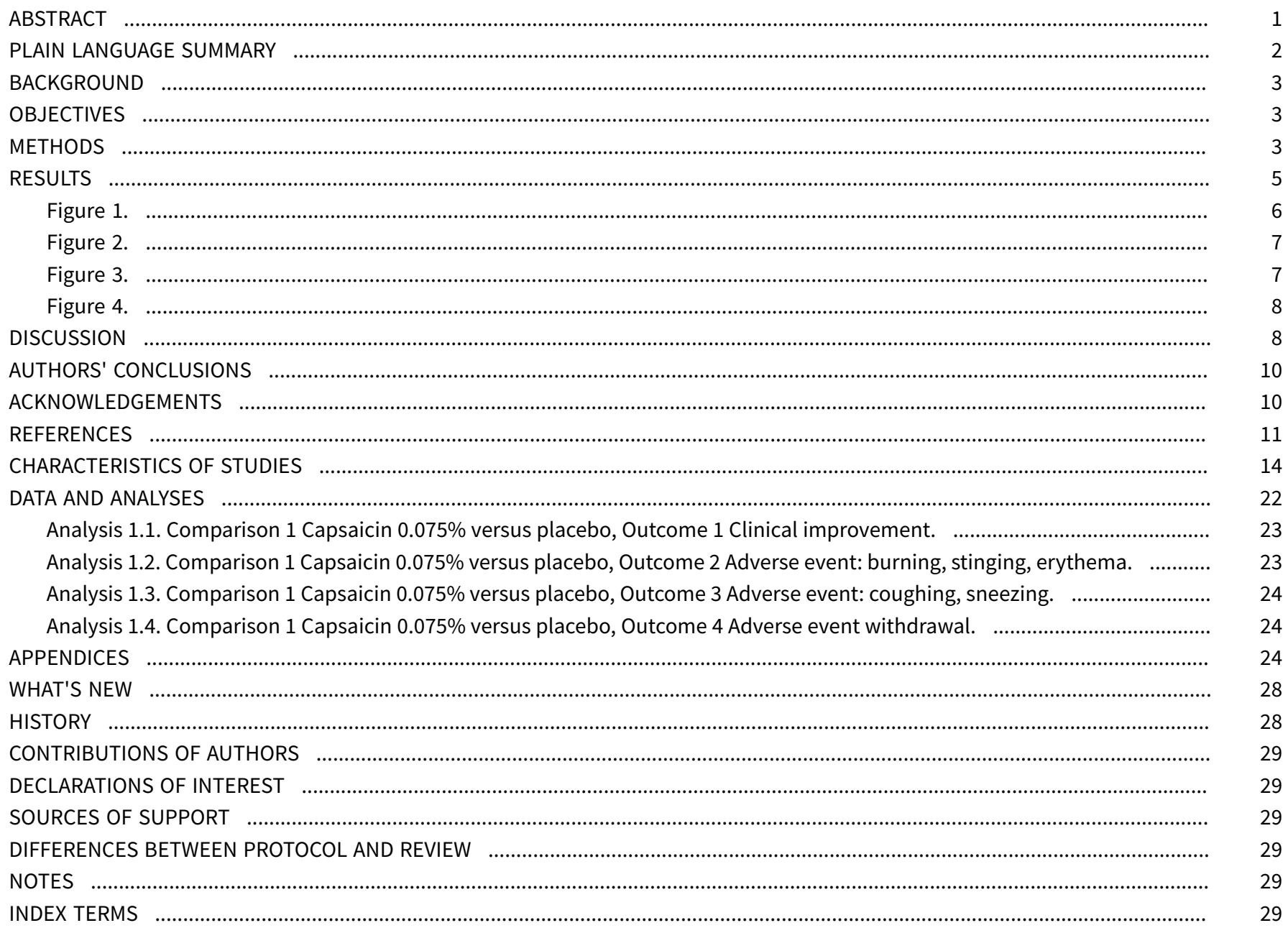


[Intervention Review]

\title{
Topical capsaicin (low concentration) for chronic neuropathic pain in adults
}

Sheena Derry ${ }^{1}$, R Andrew Moore 2

1Oxford, UK. 2Plymouth, UK

Contact: Sheena Derry, Oxford, Oxfordshire, UK. sheena.derry@retired.ox.ac.uk.

Editorial group: Cochrane Pain, Palliative and Supportive Care Group.

Publication status and date: Stable (no update expected for reasons given in 'What's new'), published in Issue 5, 2019.

Citation: Derry S, Moore RA. Topical capsaicin (low concentration) for chronic neuropathic pain in adults. Cochrane Database of Systematic Reviews 2012, Issue 9. Art. No.: CD010111. DOI: 10.1002/14651858.CD010111.

Copyright ( 2019 The Cochrane Collaboration. Published by John Wiley \& Sons, Ltd.

\begin{abstract}
A B S T R A C T
Background

Topical creams with capsaicin are used to treat pain from a wide range of chronic conditions including neuropathic pain. Following application to the skin capsaicin causes enhanced sensitivity to noxious stimuli, followed by a period with reduced sensitivity and, after repeated applications, persistent desensitisation. There is uncertainty about the efficacy and tolerability of capsaicin for treating painful chronic neuropathies. This is an update of an earlier review of topical capsaicin for chronic neuropathic pain in adults that looked at all doses and formulations of capsaicin. The original review has now been split: here we consider only formulations using a low concentration of capsaicin (<1\%) applied several times daily over several weeks, while another review will consider a single application of capsaicin at a high concentration.
\end{abstract}

\section{Objectives}

To review the evidence from controlled trials on the efficacy and tolerability of topically applied low-concentration (<1\%) capsaicin in chronic neuropathic pain in adults.

\section{Search methods}

Cochrane CENTRAL, MEDLINE, EMBASE and Oxford Pain Relief Database, searched to July 2012.

\section{Selection criteria}

Randomised, double-blind, placebo-controlled studies of at least six weeks' duration, using low-concentration (<1\%) topical capsaicin to treat neuropathic pain.

\section{Data collection and analysis}

Two review authors independently assessed study quality and validity, and extracted data. Information was extracted on numbers of participants with pain relief (clinical improvement) after at least six weeks, and with local skin reactions, and used to calculate relative risk (or risk ratio, RR) and numbers needed to treat to benefit (NNT) and harm (NNH). Details of definition of pain relief and specific adverse events were sought.

\section{Main results}

No additional studies were identified for this update of low concentration capsaicin. Included studies were published before 1996 . Six studies (389 participants in total) compared regular application of low dose $(0.075 \%)$ capsaicin cream with placebo cream. There was substantial heterogeneity in results, probably as a result of the small number of studies each with small numbers of participants, as well as the different pain conditions studied and different definitions of "clinical success" reported. Only two studies reported data for the preferred primary outcome of at least $50 \%$ pain relief, and there were too few data for pooled analysis. Local skin reactions were more 
common with capsaicin, usually tolerable, and attenuated with time; the NNH for repeated low-dose application was 2.5 (95\% confidence interval $(\mathrm{Cl}) 2.1$ to 3.1). All studies satisfied minimum criteria for quality and validity, but maintenance of blinding remains a potential problem.

\section{Authors' conclusions}

There were insufficient data to draw any conclusions about the efficacy of low-concentration capsaicin cream in the treatment of neuropathic pain. The information we have suggests that low-concentration topical capsaicin is without meaningful effect beyond that found in placebo creams; given the potential for bias from small study size, this makes it unlikely that low-concentration topical capsaicin has any meaningful use in clinical practice. Local skin irritation, which was often mild and transient but may lead to withdrawal, was common. Systemic adverse effects were rare.

\section{PLAIN LANGUAGE SUMMARY}

\section{Low-concentration capsaicin applied to the skin for chronic neuropathic pain in adults}

Neuropathic pain is caused by damage to nerves, either from injury or disease. Pain is described as chronic if it has been experienced on most days for at least three months. It is unlikely that topical (rubbed on the skin), low-concentration (< $1 \%$ ) capsaicin provides any useful pain relief in neuropathic pain conditions. It is known to cause local skin irritation such as burning and stinging. 


\section{B A C K G R O U N D}

This is an update of a review first published in 2009 (Derry 2009) that reviewed all strengths and formulations of capsaicin. At the time of publication of that review there were very few data for the new high-concentration (8\%) patch, but that formulation has now been further developed. We decided to split the review into low $(<1 \%)$ and high ( $8 \%$ ) concentration formulations because the conditions of their use are completely different, and because of the 100-fold difference in concentration of capsaicin between them.

\section{Description of the condition}

Neuropathic pain occurs as a consequence of damage to, or dysfunction in, the central nervous system (CNS) (e.g. cerebrovascular accident, multiple sclerosis or spinal cord injury) or peripheral nervous system (PNS) (e.g. painful diabetic neuropathy (PDN), postherpetic neuralgia (PHN), surgery). The nature of the pain sensation is variable: it is often described as a burning sensation; a sharp, stabbing or shooting pain; or similar to an electric shock. Topical agents are most likely to be used for localised, peripheral neuropathies. This review includes studies in which participants had experienced neuropathic pain for at least three months.

Data for the incidence of neuropathic pain is difficult to obtain, but one systematic review of prevalence and incidence in the Oxford region of the UK indicates prevalence rates per 100,000 of 34 for $\mathrm{PHN}, 400$ for diabetic neuropathy and trigeminal neuropathy, and 2000 for fibromyalgia (McQuay 2007). Different estimates in the UK indicate incidences per 100,000 person-years observation of 40 (95\% confidence intervals (CI) 39 to 41 ) for PHN, 27 (26 to 27) for trigeminal neuralgia, 1 ( 1 to 2 ) for phantom limb pain, and 15 (15 to 16) for PDN, with rates decreasing in recent years for phantom limb pain and PHN and increasing for PDN (Hall 2006). The prevalence of neuropathic pain in Austria was reported as being 3.3\% (Gustorff 2008). More recent surveys tend to agree that around $15 \%$ to $25 \%$ of patients with chronic pain (at least moderate pain lasting three months or longer) have neuropathic symptoms (Ohayon 2012; Toth 2009; Yawn 2009), and one systematic review of prevalence and incidence studies showed that the percentage with neuropathic symptoms varies with painful condition (Sadosky 2008).

\section{Description of the intervention}

Topical medications are applied externally and are taken up through the skin. They exert their effects close to the site of application, and there is no substantial systemic uptake or distribution. This compares with transdermal application, where the medication is applied externally and is taken up through the skin, but relies on systemic distribution for its effect.

Topical creams with capsaicin are used to treat pain from a wide range of chronic conditions including PHN and diabetic neuropathy, osteoarthritis and rheumatoid arthritis, in addition to pruritus, psoriasis, mastectomy pain and cluster headaches. The creams typically contain capsaicin $0.025 \%$ or $0.075 \%$, but in some countries $0.25 \%$ creams are available (Martindale 2012). Capsaicin is available in the UK on prescription only but, according to the British National Formulary, may be present in small quantities in topical rubefacients (a substance for external application producing redness of the skin, or erythema) sold through pharmacies (BNF 2012). It is also available over the counter in some other countries. In England in 2011 there were almost 200,000 prescriptions for topical capsaicin products (PCA 2011).

\section{How the intervention might work}

Capsaicin is the active compound present in chilli peppers, responsible for making them hot when eaten. It binds to nociceptors (sensory receptors responsible for sending signals that cause the perception of pain) in the skin, and specifically to the TRVP1 receptor, which controls movement of sodium and calcium ions across the cell membrane. Initially, binding opens the ion channel (influx of sodium and calcium ions), causing depolarisation and the production of action potentials, which are usually perceived as itching, pricking or burning sensations. Repeated applications or high concentrations give rise to a long-lasting effect, which has been termed 'defunctionalisation', probably owing to a number of different effects that together overwhelm the cell's normal functions, and can lead to reversible degeneration of nerve terminals (Anand 2011).

Adverse events from capsaicin are mainly at the application site (burning, stinging, erythema), and usually attenuate with time and repeated applications. Achieving double-blind conditions in placebo-controlled trials using capsaicin can, however, be difficult. Systemic events are rare. Respiratory irritation has also been reported from inhalation of the dried cream (Rains 1995).

\section{Why it is important to do this review}

Earlier reviews of topical capsaicin for neuropathic pain (Derry 2009; Mason 2004) found only a limited amount of information for limited efficacy in pain relief, but suggested that capsaicin might be a useful adjunct or used as a sole therapy for some patients unresponsive to, or intolerant of, other treatments. Those reviews considered all concentrations of capsaicin, and the decision was made to update and split the Cochrane review according to concentration since the concentration of capsaicin and method of application was so different. This review considers only studies using low-concentration formulations, while another review by the same authors (in preparation) considers highconcentration formulations. Recent revisions to guidelines also required that the data were re-analysed so that the evidence presented met new, more stringent, evidence standards. A review of the current evidence for the efficacy of topical capsaicin for chronic neuropathic pain in adults is needed for purchasers of healthcare products, prescribers, and consumers to make informed choices about their use.

\section{O B JECT IVES}

To review the evidence from controlled trials on the efficacy and tolerability of topically applied low-concentration $(<1 \%)$ capsaicin in neuropathic pain in adults.

\section{METHODS}

\section{Criteria for considering studies for this review}

\section{Types of studies}

We included randomised controlled double-blind trials comparing low-concentration $(<1 \%)$ topical capsaicin cream with placebo or other active treatment for neuropathic pain, with at least 10 participants per treatment arm. Studies published only as abstracts or studying experimentally induced pain were excluded. 


\section{Types of participants}

Adult participants (aged 16 years or more) with neuropathic pain of at least moderate intensity (Collins 1997) resulting from any cause, with a duration of at least three months and as defined in the study using accepted diagnostic criteria.

\section{Types of interventions}

Included studies had at least one treatment arm using lowconcentration $(<1 \%$ ) topical capsaicin cream, and a comparator arm using placebo or other active treatment. Treatment had to be applied three or four times daily for a minimum of six weeks.

\section{Types of outcome measures}

Information was sought on participant characteristics: age, sex, and condition treated.

\section{Primary outcomes}

The primary outcome was 'clinical improvement', ideally a 50\% reduction in pain or equivalent, measured using validated scales such as a visual analogue scale (VAS) or a categorical scale (Moore 1998a). The following hierarchy of outcomes, in order of preference, was used to extract data for the primary outcome:

- patient-reported reduction in pain of at least $50 \%$;

- patient-reported global assessment of treatment of 'very good' or 'excellent';

- 'none' or 'slight' pain on movement;

- 'none' or 'slight' pain on rest or spontaneous pain;

- patient-reported reduction in pain of at least $30 \%$;

- undefined 'improvement'.

We intended to use the first three categories of the hierarchy as our highest level of evidence (AUREF 2012).

Physician or investigator reported outcomes of efficacy were not used.

\section{Secondary outcomes}

Secondary outcomes were:

- numbers of participants with adverse events: local and systemic, and cough;

- numbers of withdrawals: all cause, lack of efficacy and adverse events.

We anticipated that outcomes would be reported after different durations of treatment, and extracted data reported as close to eight weeks as possible, but not less than six weeks. Where longer duration outcomes were available these were also extracted. We also anticipated that reporting of adverse events would vary between trials with regard to the terminology used, method of ascertainment, and categories that are reported (e.g. occurring in at least $5 \%$ of patients or where there is a statistically significant difference between treatment groups). Care was taken to identify these details.

\section{Search methods for identification of studies}

\section{Electronic searches}

The following databases were searched:
- MEDLINE via Ovid (4 July 2012);

- EMBASE via Ovid (4 July 2012);

- Cochrane Central Register of Controlled Trials (CENTRAL) (Issue 6, 2012);

- Oxford Pain Relief Database (Jadad 1996a).

See Appendix 1 for the MEDLINE search strategy, Appendix 2 for the EMBASE search strategy, and Appendix 3 for the CENTRAL search strategy.

There was no language restriction.

\section{Searching other resources}

We also searched the reference lists of review articles and included studies, together with a clinical trials database (www.clinicaltrials.gov). We did not search grey literature and short abstracts. Manufacturers have previously (Mason 2004) been asked for details of unpublished studies.

\section{Data collection and analysis}

Two review authors independently selected the studies for inclusion, assessed methodological quality and study validity, and extracted data. Disagreements were resolved through discussion.

\section{Selection of studies}

Two review authors reviewed the titles and abstracts of studies identified by the searches on screen to eliminate those that clearly did not satisfy inclusion criteria. Full reports of the remaining studies were obtained to determine inclusion in the review. We considered crossover studies only if data from the first treatment period were reported separately. Studies in oral, ocular or buccal diseases, and in musculoskeletal conditions were excluded.

\section{Data extraction and management}

Information on participants, interventions and outcomes from the original reports was abstracted into a standard data extraction form. We did not contact authors for further information.

\section{Assessment of risk of bias in included studies}

Included studies were assessed for methodological quality using the five-point Oxford Quality Scale (Jadad 1996b) that considers randomisation, blinding, and study withdrawals and drop-outs. We also completed a 'Risk of bias' table for which each study was assessed for adequacy of random sequence generation, allocation concealment, blinding, incomplete outcome data, and size.

\section{Measures of treatment effect}

We used relative risk (or 'risk ratio', RR) to establish statistical difference. Numbers needed to treat (NNT) and pooled percentages were used as absolute measures of benefit or harm.

We used the following terms to describe adverse outcomes in terms of harm or prevention of harm:

- when significantly fewer adverse outcomes occur with naproxen than with control (placebo or active) we used the term the number needed to treat to prevent one event (NNTp).

- when significantly more adverse outcomes occur with naproxen compared with control (placebo or active) we used the term the number needed to harm or cause one event (NNH). 


\section{Unit of analysis issues}

We accepted randomisation to individual patient only.

\section{Dealing with missing data}

The most likely source of missing data was expected to be from participants dropping out from the studies. We looked specifically for evidence of 'last observation carried forward' and used a dichotomous responder analysis, where a responder was defined as a participant who experienced the predefined outcome and remained in the study (e.g. did not withdraw due to adverse events). Last observation carried forward is a potential source of major bias in chronic pain studies (Moore 2012).

For all outcomes we carried out analyses, as far as possible, on a modified intention-to-treat (ITT) basis (i.e. we included all participants who were randomised and received an intervention). Where sufficient information was reported, we added back missing data in the analyses we undertook.

\section{Assessment of heterogeneity}

We assessed heterogeneity of studies visually (L'Abbe 1987). Where data could be pooled, we reported the $I^{2}$ statistic.

\section{Assessment of reporting biases}

We planned to assess publication bias by examining the number of participants in studies with zero effect (RR of 1.0) needed for the point estimate of the NNT to increase beyond a clinically useful level (Moore 2008). In this case, we specified a clinically useful level as an NNT of 10 for clinical improvement at 8 weeks.

\section{Data synthesis}

Where appropriate we planned to calculate relative benefit (RB) and RR estimates with $95 \% \mathrm{Cl}$ using a fixed-effect model (Morris 1995). NNT and NNH with $95 \% \mathrm{Cls}$ would be calculated using the pooled number of events, using the method devised by Cook and Sackett (Cook 1995). A statistically significant difference from control was assumed when the $95 \% \mathrm{Cl}$ of the RR or RB did not include the number one.

\section{Subgroup analysis and investigation of heterogeneity}

We planned to carry out subgroup analysis for concentration of capsaicin and diagnosis of neuropathic pain.

\section{Sensitivity analysis}

We planned to carry out sensitivity analyses for study outcome ( $\geq 50 \%$ pain reduction versus 'any improvement'), study size, and methodological quality (two versus $\geq$ three).

At least 200 participants had to be available in any of these different contexts before information was pooled (Moore 1998b).

\section{RES U L T S}

\section{Description of studies}

\section{Included studies}

New searches for this split and updated review looking at lowconcentration capsaicin did not identify any additional studies.
Seven studies, with 1600 participants in total, fulfilled the entry criteria (Bernstein 1989; Biesbroeck 1995; CSG 1992; Ellison 1997; Low 1995; Watson 1992; Watson 1993). Details of included studies are in the 'Characteristics of included studies' table. Four studies identified (Basha 1991; Donofrio 1991; Scheffler 1991; Tandan 1992) were reports of parts of a multicentre study (CSG 1992), only one of which (Tandan 1992, 22 participants) provided any additional data.

Neuropathic pain conditions studied were PHN, diabetic neuropathy, distal painful polyneuropathy, human immunodeficiency virus (HIV) neuropathy, postmastectomy pain, and postsurgical cancer pain. In all studies pain was of at least moderate severity and was frequently unresponsive to, or poorly controlled by, conventional therapy.

Capsaicin $0.075 \%$ in a cream base was used by 449 participants in the seven studies, and was applied four times daily to sites of neuropathic pain for six (Bernstein 1989; Biesbroeck 1995; Watson 1992; Watson 1993), eight (CSG 1992; Ellison 1997) or 12 weeks (Low 1995). A total of 325 participants received placebo cream, and 117 received the active comparator oral amitriptyline.

Because application of capsaicin to the skin, even at low concentration, may initially cause redness and a burning or stinging sensation in many individuals, maintaining the double-blind status of studies is problematic. Two studies (Biesbroeck 1995; Low 1995) included methyl nicotinate (a rubefacient, without established analgesic effects) in the first tube of placebo cream to mimic these side effects. The study using amitriptyline as an active control (Biesbroeck 1995) included in the placebo capsules benztropine to mimic dry mouth, and for the first two weeks diazepam to mimic sedation; these are expected side effects of amitriptyline.

Six studies allowed concomitant oral or transdermal drugs for neuropathic pain without change in dose or frequency (Bernstein 1989; Biesbroeck 1995; CSG 1992; Ellison 1997; Watson 1992; Watson 1993) but all topical medications were discontinued at least seven days before the study. One study did not mention concomitant medication (Low 1995).

One study (Low 1995) included only participants with bilateral symmetric chronic painful peripheral neuropathy and participants were randomised by side, left versus right leg. We included this study with the intention to carry out a sensitivity analysis since it does not strictly conform to our pre-specified unit of analysis.

\section{Excluded studies}

Eleven studies were excluded after reading the full reports (Chad 1990; Fusco 1992; McCarty 1994; McCleane 2000; Paice 2000; Peikert 1991; Pfeifer 1993; Robbins 1998; Vickers 1998; Watson 1988; Watson 1989). Reasons for exclusion are stated in the 'Characteristics of excluded studies' table.

\section{Risk of bias in included studies}

Each study was scored for methodological quality. Five studies were given a quality score of four (Bernstein 1989; Biesbroeck 1995; Ellison 1997; Low 1995; Watson 1993), and two studies a score of three (CSG 1992; Watson 1992). Points were lost for failure to provide adequate details of the methods of randomisation and blinding, and of withdrawals. Full details can be found in the 'Characteristics of included studies' table. 
The 'Risk of bias' table has been completed for all studies for sequence generation, allocation concealment and blinding, incomplete outcome data, and size.

Figure 1. Methodological quality graph: review authors' judgements about each methodological quality item presented as percentages across all included studies.

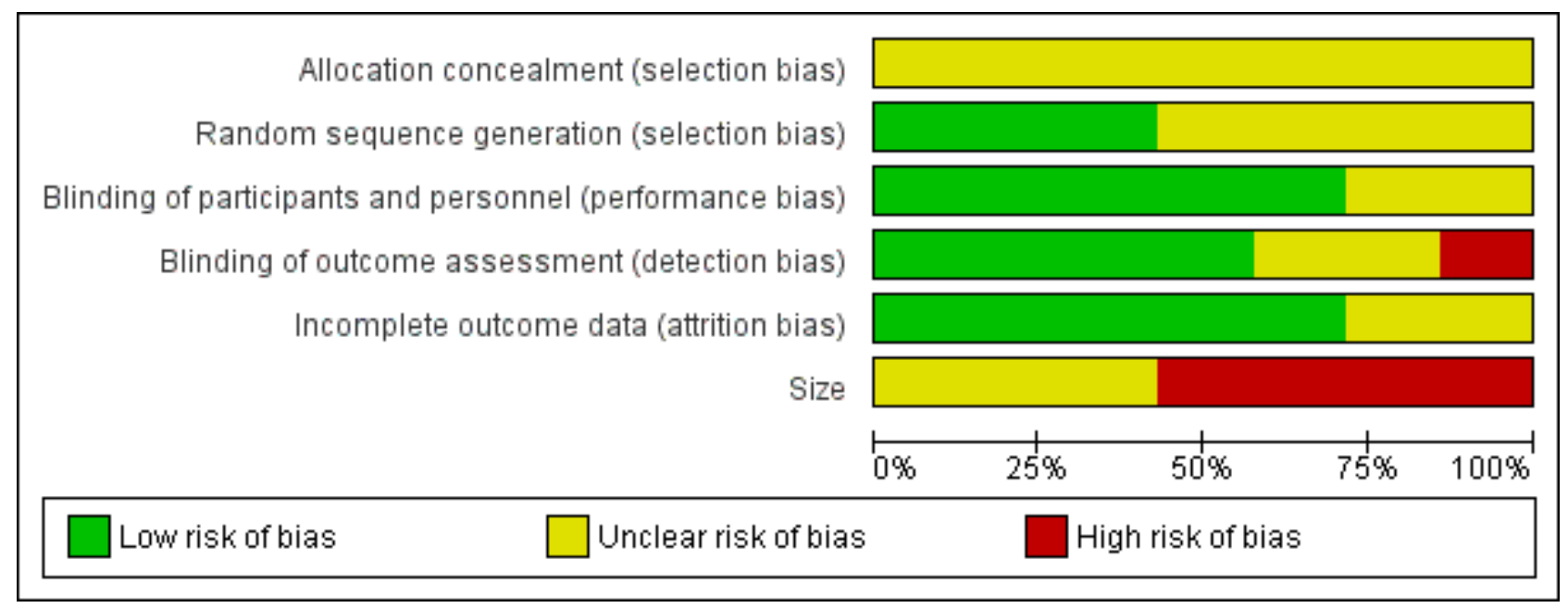

\section{Effects of interventions}

Although no new studies were identified for this update, there have been substantial changes in understanding of potential biases, both in individual studies and in the review process since the original review was carried out, so a re-analysis of the available data was required (AUREF 2012; Moore 2010; Moore 2012). Details of efficacy outcomes for individual studies are in Appendix 4, and for adverse events and withdrawals in Appendix 5.

\section{Clinical improvement}

Six studies compared regular application of low-concentration capsaicin $(0.075 \%)$ cream with placebo cream. Only two of the studies reported outcomes at the highest level of evidence. Watson 1992 used the achievement of at least 50\% pain relief as a primary outcome measure, though in only 25 participants; Ellison 1997 reported the proportion of participants with a decreased pain score of at least $75 \%$ in 99 participants. Of the remaining studies, one (Bernstein 1989) reported the proportion of participants achieving at least $40 \%$ pain relief, Low 1995 reported the proportion of participants with unspecified improvement, and Tandan 1992 (part of CSG 1992) reported pain reduction by at least one category. Efficacy for the multicentre study as a whole (CSG 1992) was reported only as group mean pain relief, and Watson 1993
See Figure 1 for the 'Risk of bias' table. 
Figure 2. Forest plot of comparison: 1 Capsaicin $0.075 \%$ versus placebo, outcome: 1.1 Clinical improvement.

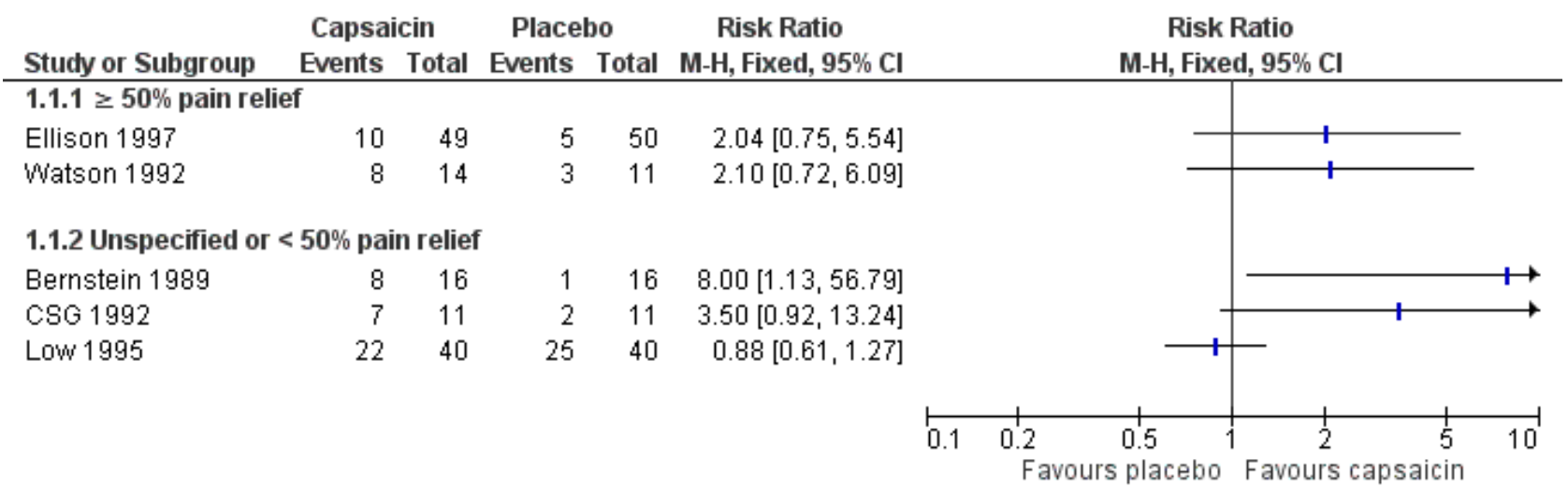

The L'Abbé plot (Figure 3) showed considerable scatter for the studies using multiple applications of low-dose capsaicin, which is likely to be because of the different neuropathic conditions treated (clinical heterogeneity), the different definitions of 'clinical success', and the random play of chance in small studies.

Figure 3. L'Abbé plot showing response rates for any improvement in studies using low-concentration capsaicin. Size of circle is proportional to size of study (inset scale). Blue circles are studies reporting the outcome of $\geq 50 \%$ pain relief.

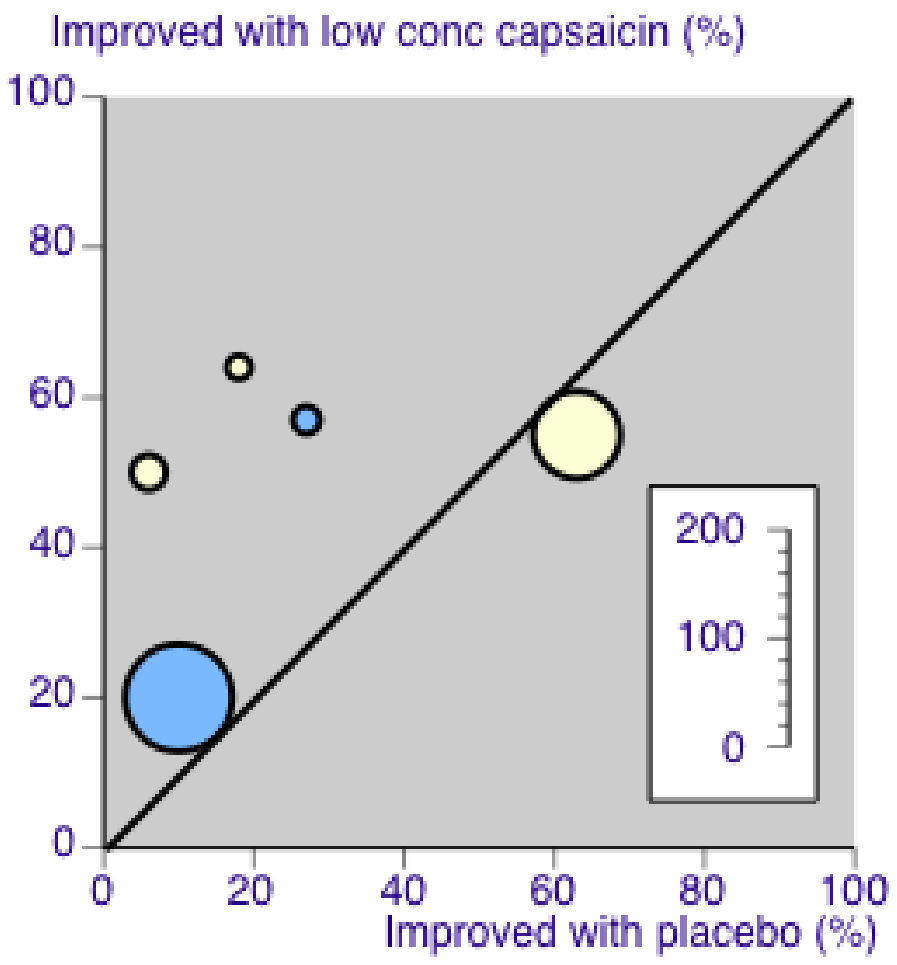

\section{Subgroup analysis}

There were insufficient data for subgroup analysis.

\section{Sensitivity analysis}

There were insufficient data for any sensitivity analyses.

\section{Adverse events}

Reporting of adverse events was inconsistent and incomplete (Appendix 5). One study (CSG 1992) specified that side effects of concurrent systemic medication were not reported, and Biesbroeck 1995 , in which capsaicin was compared to amitriptyline, specified that adverse events were excluded if they were judged likely to be caused by the mimicking agents or unrelated to either drug. Other studies said that they recorded only 'adverse drug experiences', or 'side effects' or 'adverse reactions to study medication'. Most studies did not report the methods used to collect adverse event data. 


\section{Local skin reactions (burning, stinging, erythema and pruritus)}

All the included studies reported on local skin reactions to capsaicin. Generally they were more common with capsaicin than placebo or amitriptyline, appeared early in treatment, and either disappeared or were reduced in frequency and severity after one to two weeks of treatment.

Local skin reactions were variously reported as numbers of participants with individual symptoms, such as 'burning', 'stinging', 'erythema', 'redness', 'rash', 'pruritus' and 'itch', or with combinations of these symptoms, or with 'total skin adverse effects'. It was not usually possible to determine the number of participants with any kind of local skin reaction since more than one symptom may appear in an individual participant. We chose to analyse 'burning, stinging, erythema and pruritus', using the number of participants reporting the most common of these symptoms in individual studies. This almost certainly underestimates the number of participants affected by these symptoms.

Five studies contributed data for comparison with placebo (Bernstein 1989; CSG 1992; Low 1995; Watson 1992; Watson 1993) (Figure 4).

\section{Figure 4. Forest plot of comparison: 1 Capsaicin $0.075 \%$ versus placebo, outcome: 1.2 Adverse event: burning,} stinging, erythema.

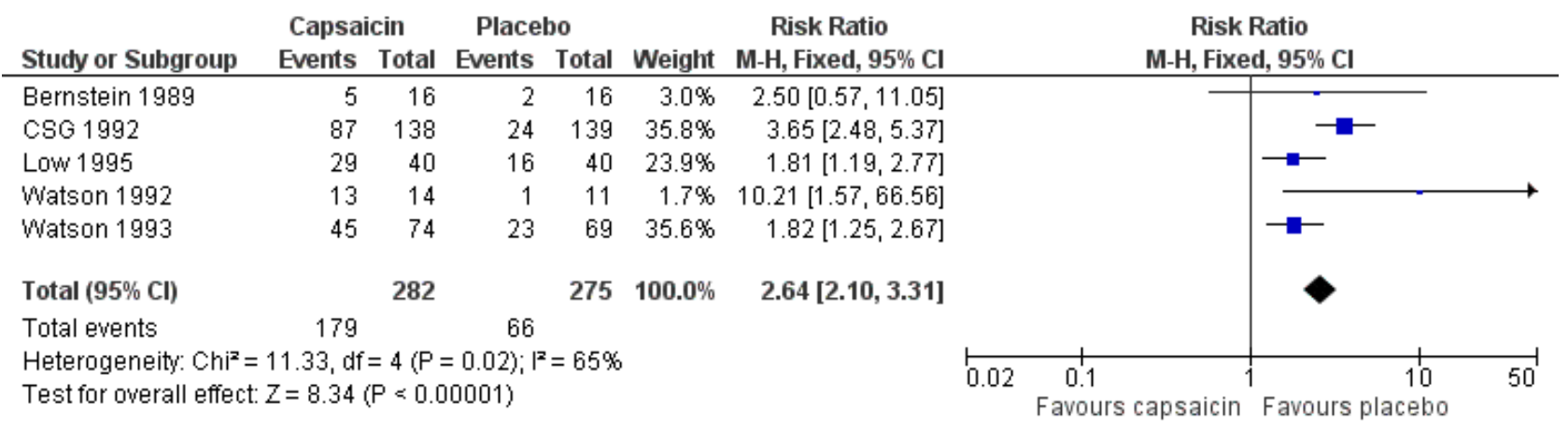

- The proportion of participants experiencing a local skin reaction with capsaicin was $63 \%$ (179/282, range $31 \%$ to $93 \%)$;

- The proportion of participants experiencing a local skin reaction with placebo was $24 \%(66 / 275$, range $9 \%$ to $40 \%)$;

- The RR of treatment compared with placebo was 2.6 (2.1 to 3.3);

- The NNH for experiencing a local skin reaction over 6 to 8 weeks of treatment was 2.5 (2.1 to 3.1)

Removing the study that included a mimicking agent in the first tube of placebo cream (Low 1995) did not change the results.

One study (Ellison 1997) did not provide data for the first period only of the cross-over, but reported that there was more burning, redness and coughing with capsaicin than placebo $(P<0.0001)$.

\section{Coughing and sneezing}

Coughing and sneezing are thought to result from inhalation of particles of dried capsaicin cream. Five studies contributed data for comparison with placebo (Bernstein 1989; CSG 1992; Low 1995; Watson 1992; Watson 1993).

- The proportion of participants experiencing coughing or sneezing with capsaicin $(0.075 \%)$ was $9.2 \%$ (26/282, range $0 \%$ to $13 \%)$;

- The proportion of participants experiencing coughing or sneezing with placebo was $1.4 \%$ (4/275, range $0 \%$ to $3 \%)$;

- The RR of treatment compared with placebo was 5.7 (2.1 to 15) (Analysis 1.3);

- The NNH for experiencing coughing or sneezing over 6 to 8 weeks of treatment was 13 (8.7 to 25 ).

\section{Systemic adverse events}

A number of studies did not report any information for systemic adverse events, and in those that did, they were uncommon and did not differ from placebo. No analysis was possible.

\section{Serious adverse events}

Serious adverse events were uncommon, and none were judged possibly related to study medication.

\section{Withdrawals}

Withdrawals due to adverse events were nearly all because of skin reactions. A total of 37 withdrawals were reported in 242 participants (15\%) with capsaicin $0.075 \%$ and seven in 235 participants (3\%) with placebo in four studies (Bernstein 1989; CSG 1992; Watson 1992; Watson 1993), giving a RR of 5.0 (2.3 to 11) and a NNT of 8.1 (5.7 to 14) (Analysis 1.4). The remaining three studies (Biesbroeck 1995; Ellison 1997; Low 1995) did not provide data for comparison.

Withdrawals for other reasons were generally poorly reported. Some studies reported withdrawals or exclusions due to protocol violation, non-compliance, treatment failure and other health problems (Appendix 5). No further statistical analysis of withdrawals was carried out.

\section{DISCUSSION}

\section{Summary of main results}

We identified only a small number of studies with a small numbers of participants. The studies recruited participants with various different types of neuropathic pain and used different definitions of 
clinical success; some reported only group mean data for efficacy. There were too few data to draw any conclusions about the efficacy of low-concentration capsaicin $(0.075 \%)$ cream applied three or four times daily over 6 to 12 weeks for relief of neuropathic pain.

This might be compared with information we have for oral treatments for painful neuropathic conditions. For example, in PDN the NNT for at least $50 \%$ pain relief in trials lasting at least 8 weeks is 5.1 (3.9 to 7.3) for duloxetine $60 \mathrm{mg}$ or $120 \mathrm{mg}$ daily (Sultan 2008; 1024 participants), and 5.0 (4.0 to 6.6) for pregabalin $600 \mathrm{mg}$ daily (Moore 2009; 1005 participants).

Use of capsaicin, even at this low concentration, is associated with increased local skin reactions, primarily burning, stinging and erythema. For every five individuals treated with low-concentration capsaicin for 6 to 8 weeks, two will experience local skin reactions who would not have done so with placebo (vehicle cream alone). These effects tend to be mild to moderate in intensity, but lead to withdrawal in some individuals. In those who can tolerate them, they generally disappear or become less intense after one to two weeks of use. Coughing and sneezing are also increased with capsaicin compared with placebo, and are thought to result from inhalation of particles of dried capsaicin cream.

\section{Overall completeness and applicability of evidence}

The very limited amount of good data available prevented sensible analysis. Importantly there were insufficient data to allow analysis by condition, but there is now evidence that different response rates to treatment are seen in different neuropathic conditions (Moore 2009). The L'Abbé plot shows considerable scatter, reflecting the small numbers of participants and different definitions of 'improvement' in these studies, but may also be due, in part, to the different neuropathic pain conditions studied (Figure 3 ).

The decisions a priori to exclude studies of less than six weeks' duration, and not to use physician-reported outcomes, both reduced the amount of evidence available to us. We feel this is justified because other studies in neuropathic pain have shown that studies of shorter duration tend to overestimate treatment effect, sometimes considerably (Straube 2010), and do not accurately reflect treatment of chronic conditions. Similarly, investigator- or physician-reported outcomes do not reliably correspond to patient outcomes. In particular, four studies of 4 weeks' duration were excluded (Chad 1990; McCarty 1994; McCleane 2000; Paice 2000). These studies enrolled 329 participants, 90 of whom were treated with capsaicin $0.075 \%$, and 21 with capsaicin $0.025 \%$. Only one study (59 participants) provided dichotomous data for the efficacy outcome, so the amount of useable data excluded was small.

All included studies used standard validated scales to measure pain intensity and pain relief, but outcome definitions for improvement in pain differed between studies. Only two studies reported at least substantial levels of pain relief $(\geq 75 \%$ in Ellison 1997 and $\geq 50 \%$ in Watson 1992) according to the Initiative on Methods, Measurement, and Pain Assessment in Clinical Trials (IMMPACT) consensus criteria (Dworkin 2008). One study reported at least moderate levels of pain relief ( $\geq 40 \%$ Bernstein 1989), while one (Tandan 1992 (part of CSG 1992)) used pain decreased by at least one category, and one did not define improvement (Low 1995). The remaining three studies reported only mean data or physician assessments for pain. Such heterogeneity in outcomes makes combining studies for analysis difficult and would reduce the validity of the result.
Some types of neuropathic pain appear to be more difficult to treat than others (Moore 2009). Although most studies included in this review recruited participants with neuropathic pains that have shown some response to other treatments, in most it was unresponsive to or poorly controlled by conventional therapy, so may have been more treatment resistant. However, neuropathic pain unresponsive to one treatment may well be responsive to others (Watson 1998).

\section{Quality of the evidence}

The main problem was the small number of studies and participants. Overall the methodological quality was adequate, with all included studies indicating that they were both randomised and double blind, and scoring a minimum of $3 / 5$ on the Oxford Quality Score. Points were lost for failure to report details of the methods of randomisation and blinding, and also for failure to report withdrawals in some of the earlier studies adequately.

While all the studies claimed to be double blind, the propensity for capsaicin to cause skin irritation makes maintenance of blinding of treatment groups difficult. This was recognised in all studies, and two took steps to include a mimicking agent (a rubefacient). In all control groups, some individuals experienced skin irritation, reporting events similar to those in the capsaicin groups, but the frequency of such reactions was substantially different, and doubt must remain about the adequacy of the blinding.

There there is a considerable potential for residual bias in the evidence we have. In part, this comes from the small size of the studies. Recent evidence in chronic pain is that studies with treatment arm sizes below 100 participants overestimate treatment effects compared with larger studies (Nuesch 2010). No single study for topical capsaicin had useable efficacy data in more than 50 participants in a treatment arm, and most were much smaller. There were insufficient amounts of data for a pooled analysis.

Reporting of adverse events was inconsistent, making analysis difficult. Estimates for skin reactions presented here may underestimate their frequency. Problems with reporting of adverse events have been highlighted before (Edwards 1999; Ioannidis 2001; Loke 2001).

\section{Agreements and disagreements with other studies or reviews}

There have been no relevant new studies identified since the review of capsaicin for both neuropathic and musculoskeletal conditions in 2004 (Mason 2004), the earlier Cochrane review (Derry 2009), and a review conducted as part of National Institute for Health and Clinical Evidence (NICE) guidance on neuropathic pain (NICE 2010). However, by adopting more rigorous criteria for study inclusion and more rigorous outcome measures, the amount of data available for analysis has been substantially reduced such that we are no longer able to draw any firm conclusions about clinically meaningful efficacy. This does not necessarily mean that the earlier reviews were wrong and that capsaicin $0.075 \%$ cream is ineffective, but that there is reason to believe that those results could be biased and overestimate efficacy. In particular the major effects of imputation methods (Moore 2012), study outcome and duration (Moore 2010), and size (Nuesch 2010), while suspected for some time, have been emphasised in recent years. 
Not all guidelines agree about use of topical low-concentration capsaicin. The NICE guidance (NICE 2010) and review concluded that low-concentration topical capsaicin was not recommended across all neuropathic pain conditions in non-specialist settings. A recent evidence-based guideline for treatment of PDN (Bril 2011) recommended that capsaicin $0.075 \%$ cream should be considered (Level B evidence), but did not carry out any quantitative analysis. Similarly, Smith 2011 suggested that topical capsaicin may be considered for PDN. The latest European Federation of Neurological Societies (EFNS) guidelines on pharmacological treatment of neuropathic pain recommend capsaicin cream only as a second- or third-line option for PHN (Attal 2010), and a review of pharmacological treatments for painful HIV-associated sensory neuropathy found evidence of efficacy only for the highconcentration patch (Phillips 2010). High-concentration topical capsaicin is the subject of a separate Cochrane review by the same authors (in preparation).

\section{AUTHORS' CONCLUSIONS}

\section{Implications for practice}

There were insufficient data to draw any conclusions about the efficacy of low-concentration $(<1 \%)$ capsaicin cream in the treatment of neuropathic pains. Use of capsaicin cream commonly causes local skin irritation, which is often mild and transient but may lead to withdrawal, and is common. Systemic adverse effects are rare. What information we have suggests that low-concentration topical capsaicin is without meaningful effect beyond that found in placebo creams; given the potential for bias from small study size, this makes it unlikely that low-concentration topical capsaicin has any meaningful use in clinical practice.

\section{Implications for research}

Studies using repeated applications of low-concentration capsaicin have not convincingly demonstrated good efficacy. No new studies of low-concentration topical capsaicin have been published since 1997 and been found worthy of inclusion in this review. It seems unlikely that further research with low-concentration creams is worthwhile. A new strategy has emerged, using a single application of high-dose capsaicin, facilitated by pretreatment with local anaesthetic. This formulation is the subject of new studies and is the subject of a separate Cochrane review.

\section{ACKNOWLEDGEMENTS}

Ros Lloyd and Henry McQuay were authors on the original review. SD is supported by the Pain Research Trust, Oxford, UK. 


\section{RE F E R E N C E S}

\section{References to studies included in this review}

Bernstein 1989 \{published data only\}

Bernstein JE, Korman NJ, Bickers DR, Dahl MV, Millikan LE. Topical capsaicin treatment of chronic postherpetic neuralgia. Journal of the American Academy of Dermatology 1989;21(2):265-70.

\section{Biesbroeck 1995 \{published data only\}}

Biesbroeck R, Bril V, Hollander P, Kabadi U, Schwartz S, Singh SP, et al. A double-blind comparison of topical capsaicin and oral amitriptyline in painful diabetic neuropathy. Advances in Therapy 1995;12(2):111-20.

\section{CSG 1992 \{published data only\}}

Basha KM, Whitehouse FW. Capsaicin: a therapeutic option for painful diabetic neuropathy. Henry Ford Hospital Medical Journal 1991;39:138-40.

* Capsaicin Study Group. Effect of treatment with capsaicin on daily activities of patients with painful diabetic neuropathy. Diabetes Care 1992;15(2):159-65.

Donofrio P, Walker F, Hunt V, Tandan R, Fries T, Lewis G, et al. Treatment of painful diabetic neuropathy with topical capsaicin: a multicenter, double-blind, vehicle-controlled study. Archives of Internal Medicine 1991;151:2225-9.

Scheffler NM, Sheitel PL, Lipton MN. Treatment of painful diabetic neuropathy with capsaicin $0.075 \%$. Journal of the American Podiatric Medical Association 1991;81:288-93.

Tandan R, Lewis GA, Krusinski PB, Badger GB, Fries TJ. Topical capsaicin in painful diabetic neuropathy. Controlled study with long-term follow-up. Diabetes Care 1992;15:8-14.

\section{Ellison 1997 \{published data only\}}

Ellison N, Loprinzi CL, Kugler J, Hatfield AK, Miser A, Sloan JA, et al. Phase III placebo-controlled trial of capsaicin cream in the management of surgical neuropathic pain in cancer patients. Journal of Clinical Oncology 1997;15(8):2974-80.

\section{Low 1995 \{published data only\}}

Low PA, Opfer-Gehrking TL, Dyck PJ, Litchy WJ, O'Brien PC. Double-blind, placebo-controlled study of the application of capsaicin cream in chronic distal painful polyneuropathy. Pain 1995;62(2):163-8.

\section{Watson 1992 \{published data only\}}

Watson CP, Evans RJ. The postmastectomy pain syndrome and topical capsaicin: a randomized trial. Pain 1992;51(3):375-9.

\section{Watson 1993 \{published data only\}}

Watson CP, Tyler KL, Bickers DR, Millikan LE, Smith S, Coleman E. A randomized vehicle-controlled trial of topical capsaicin in the treatment of postherpetic neuralgia. Clinical Therapeutics 1993;15(3):510-26.

\section{References to studies excluded from this review}

Chad 1990 \{published data only\}

Chad DA, Aronin N, Lundstrom R, McKeon P, Ross D, Molitch M, et al. Does capsaicin relieve the pain of diabetic neuropathy? Pain 1990;42(3):387-8.

\section{Fusco 1992 \{published data only\}}

Fusco BM, Alessandri M. Analgesic effect of capsaicin in idiopathic trigeminal neuralgia. Anesthesia and Analgesia 1992;74:375-7.

McCarty 1994 \{published data only\}

McCarty DJ, Csuka M, McCarthy G, Trotter D. Treatment of pain due to fibromyalgia with topical capsaicin: a pilot study. Seminars in Arthritis and Rheumatism 1994;23(Suppl 3):41-7.

\section{McCleane 2000 \{published data only\}}

McCleane G. Topical application of doxepin hydrochloride, capsaicin and a combination of both produces analgesia in chronic human neuropathic pain: a randomized, doubleblind, placebo-controlled study. British Journal of Clinical Pharmacology 2000;49(6):574-9.

Paice $\mathbf{2 0 0 0}$ \{published data only\}

Paice JA, Ferrans CE, Lashley FR, Shott S, Vizgirda V, Pitrak D. Topical capsaicin in the management of HIV-associated peripheral neuropathy. Journal of Pain and Symptom Management 2000;19(1):45-52.

Peikert 1991 \{published data only\}

Peikert A, Hentrich M, Ochs G. Topical $0.025 \%$ capsaicin in chronic post-herpetic neuralgia: efficacy, predictors of response and long-term course. Journal of Neurology 1991;238:452-6.

\section{Pfeifer 1993 \{published data only\}}

Pfeifer MA, Ross DR, Schrage JP, Gelber DA, Schumer MP, Crain GM, et al. A highly successful and novel model for treatment of chronic painful diabetic peripheral neuropathy. Diabetes Care 1993;16:1103-15.

Robbins 1998 \{published data only\}

Robbins WR, Staats PS, Levine J, Fields HL, Allen RW, Campbell JN, et al. Treatment of intractable pain with topical large-dose capsaicin: preliminary report. Anesthesia and Analgesia 1998;86:579-83.

\section{Vickers 1998 \{published data only\}}

Vickers ER, Cousins MJ, Walker S, Chisholm K. Analysis of 50 patients with atypical odontalgia. A preliminary report on pharmacological procedures for diagnosis and treatment. Oral Surgery Oral Medicine Oral Pathology Oral Radiology and Endodontics 1998;85:24-32.

Watson 1988 \{published data only\}

Watson CP, Evans RJ, Watt VR. Post-herpetic neuralgia and topical capsaicin. Pain 1988;33:333-40. 
Watson 1989 \{published data only\}

Watson CP, Evans RJ, Watt VR. The post-mastectomy pain syndrome and the effect of topical capsaicin. Pain 1989;38:177-86.

\section{References to ongoing studies \\ NCT00993070 \{published data only\}}

Efficacy and safety study of topical capsaicin in painful diabetic neuropathy. www.clinicaltrials.gov [accessed 10 August 2012] 2012.

\section{Additional references}

\section{Anand 2011}

Anand P, Bley K. Topical capsaicin for pain management: therapeutic potential and mechanisms of action of the new high-concentration capsaicin $8 \%$ patch. British Journal of Anaesthesia 2011;107(4):490-502. [DOI: doi:10.1093/bja/aer260]

\section{Attal 2010}

Attal N, Cruccu G, Baron R, Haanpää M, Hansson P, Jensen TS. EFNS guidelines on the pharmacological treatment of neuropathic pain: 2010 revision. European Journal of Neurology 2010;17(9):1113-e88. [DOI: 10.1111/j.1468-1331.2010.02999.x]

\section{AUREF 2012}

Cochrane Pain, Palliative and Supportive Care Group. PaPaS author and referee guidance. http://papas.cochrane.org/papasdocuments [Accessed 11 August 2012].

\section{BNF 2012}

Rubefacients, topical NSAIDs, capsaicin, and poultices. In: Martin J, Ryan RSM editor(s). British National Formulary. Vol. 62, London: BMJ Group and RPS Publishing, 2012:676-8. [ISBN: 978-0-85369-981-1]

\section{Bril 2011}

Bril V, England J, Franklin GM, Backonja M, Cohen J, Del Toro D, et al. Evidence-based guideline: treatment of painful diabetic neuropathy: report of the American Academy of Neurology, the American Association of Neuromuscular and Electrodiagnostic Medicine, and the American Academy of Physical Medicine and Rehabilitation. Neurology 2011;76(20):1758-65. [DOI: 10.1212/ WNL.0b013e3182166ebe]

\section{Collins 1997}

Collins SL, Moore RA, McQuay HJ. The visual analogue pain intensity scale: what is moderate pain in millimetres?. Pain 1997;72(1-2):95-7.

\section{Cook 1995}

Cook RJ, Sackett DL. The number needed to treat: a clinically useful measure of treatment effect. BMJ (Clinical Research Ed) 1995;310:452-4.

\section{Dworkin 2008}

Dworkin RH, Turk DC, Wyrwich KW, Beaton D, Cleeland CS, Farrar JT, et al. Interpreting the clinical importance of treatment outcomes in chronic pain clinical trials: IMMPACT recommendations. Journal of Pain 2008;9(2):105-21. [DOI: 10.1016/j.jpain.2007.09.005]

\section{Edwards 1999}

Edwards JE, McQuay HJ, Moore RA, Collins SL. Reporting of adverse effects in clinical trials should be improved: lessons from acute postoperative pain. Journal of Pain and Symptom Management 1999;18(6):427-37. [DOI: 10.1016/ S0885-3924(99)00093-7]

\section{Gustorff 2008}

Gustorff B, Dorner T, Likar R, Grisold W, Lawrence K, Schwarz F, et al. Prevalence of self-reported neuropathic pain and impact on quality of life: a prospective representative survey. Acta Anaesthesiologica Scandinavica 2008;52(1):132-6.

\section{Hall 2006}

Hall GC, Carroll D, Parry D, McQuay HJ. Epidemiology and treatment of neuropathic pain: the UK primary care perspective. Pain 2006;122(1-2):156-62. [DOI: 10.1016/ j.pain.2006.01.030]

\section{loannidis 2001}

Ioannidis JP, Lau J. Completeness of safety reporting in randomized trials: an evaluation of 7 medical areas. JAMA 2001;285(4):437-43.

\section{Jadad 1996a}

Jadad AR, Carroll D, Moore A, McQuay H. Developing a database of published reports of randomised clinical trials in pain research. Pain 1996;66:239-46.

\section{Jadad 1996b}

Jadad AR, Moore RA, Carroll D, Jenkinson C, Reynolds DJ, Gavaghan DJ, et al. Assessing the quality of reports of randomized clinical trials: is blinding necessary?. Controlled Clinical Trials 1996;17:1-12.

\section{L'Abbe 1987}

L'Abbé KA, Detsky AS, O'Rourke K. Meta-analysis in clinical research. Annals of Internal Medicine 1987;107:224-33.

\section{Loke 2001}

Loke YK, Derry S. Reporting of adverse drug reactions in randomised controlled trials - a systematic survey. BMC Clinical Pharmacology 2001;1:3. [DOI: 10.1186/1472-6904-1-3]

\section{Martindale 2012}

Martindale: the complete drug reference [online]. At: www.medicinescomplete.com/mc/martindale/current/ [accessed 10 August 2012].

\section{Mason 2004}

Mason L, Moore RA, Derry S, Edwards JE, McQuay HJ. Systematic review of topical capsaicin for the treatment of chronic pain. BMJ (Clinical Research Ed) 2004;328(7446):991.

\section{McQuay 2007}

McQuay HJ, Smith LA, Moore RA. Chronic pain. In: Stevens A, Raferty J, Mant J, Simpson S editor(s). Health Care Needs 
Assessment. Oxford: Radcliffe Publishing Ltd, 2007:519-600. [ISBN: 978-1-84619-063-6]

\section{Moore 1998a}

Moore RA, Tramèr MR, Carroll D, Wiffen PJ, McQuay HJ. Quantitative systematic review of topically applied nonsteroidal anti-inflammatory drugs. BMJ 1998;316(7128):333-8.

\section{Moore 1998b}

Moore RA, Gavaghan D, Tramèr MR, Collins SL, McQuay HJ. Size is everything - large amounts of information are needed to overcome random effects in estimating direction and magnitude of treatment effects. Pain 1998;78(3):209-16. [DOI: 10.1016/S0304-3959(98)00140-7]

\section{Moore 2008}

Moore RA, Barden J, Derry S, McQuay HJ. Managing potential publication bias. In: McQuay HJ, Kalso E, Moore RA editor(s). Systematic Reviews in Pain Research: Methodology Refined. Seattle: IASP Press, 2008:15-23. [ISBN: 978-0-931092-69-5]

\section{Moore 2009}

Moore RA, Straube S, Wiffen PJ, Derry S, McQuay HJ. Pregabalin for acute and chronic pain in adults. Cochrane Database of Systematic Reviews 2009, Issue 3. [DOI: 10.1002/14651858.CD007076.pub2]

\section{Moore 2010}

Moore RA, Eccleston C, Derry S, Wiffen P, Bell RF, Straube S, et al. "Evidence" in chronic pain - establishing best practice in the reporting of systematic reviews. Pain 2010;150(3):386-9. [DOI: 10.1016/j.pain.2010.05.011]

\section{Moore 2012}

Moore RA, Straube S, Eccleston C, Derry S, Aldington D, Wiffen P, et al. Estimate at your peril: imputation methods for patient withdrawal can bias efficacy outcomes in chronic pain trials using responder analyses. Pain 2012;153(2):265-8. [DOI: 10.1016/j.pain.2011.10.004]

\section{Morris 1995}

Morris JA, Gardner MJ. Calculating confidence intervals for relative risk, odds ratios and standardised ratios and rates. In: Gardner MJ, Altman DG editor(s). Statistics with Confidence Confidence Intervals and Statistical Guidelines. London: British Medical Journal, 1995:50-63.

\section{NICE 2010}

National Institute for Health and Clinical Excellence. Neuropathic Pain: the Pharmacological Management of Neuropathic Pain in Adults in Non-specialist Settings. London: National Institute for Health and Clinical Excellence, 2010. [online: www.nice.org.uk/guidance/CG96]

\section{Nuesch 2010}

Nüesch E, Trelle S, Reichenbach S, Rutjes AW, Tschannen B, Altman DG. Small study effects in meta-analyses of osteoarthritis trials: meta-epidemiological study. $B M J$ 2010;341:c3515. [DOI: 10.1136/bmj.c3515]

\section{Ohayon 2012}

Ohayon MM, Stingle JC. Prevalence and comorbidity of chronic pain in the German general population. Journal of Psychiatric Research 2012;46(4):444-50. [DOI: 10.1016/ j.jpsychires.2012.01.001]

\section{PCA 2011}

Anon. Prescription Cost Analysis, England 2011. The NHS Information Centre, 2012. [ISBN: 1978-1-84636-685-7]

\section{Phillips 2010}

Phillips TJ, Cherry CL, Cox S, Marshall SJ, Rice AS. Pharmacological treatment of painful HIV-associated sensory neuropathy: a systematic review and meta-analysis of randomised controlled trials. PLoS One 2010;5(12):e14433. [DOI: 10.1371/journal.pone.0014433]

\section{Rains 1995}

Rains C, Bryson HM. Topical capsaicin. A review of its pharmacological properties and therapeutic potential in postherpetic neuralgia, diabetic neuropathy and osteoarthritis. Drugs Aging 1995;7(4):317-28.

\section{Sadosky 2008}

Sadosky A, McDermott AM, Brandenburg NA, Strauss M. A review of the epidemiology of painful diabetic peripheral neuropathy, postherpetic neuralgia, and less commonly studied neuropathic pain conditions. Pain Practice 2008;8(1):45-56. [DOI: 10.1111/ j.1533-2500.2007.00164.x]

\section{Smith 2011}

Smith HS, Argoff CE. Pharmacological treatment of diabetic neuropathic pain. Drugs 2011;71(5):557-89. [DOI: 10.2165/11588940-000000000-00000]

\section{Straube 2010}

Straube S, Derry S, Moore RA, Paine J, McQuay HJ. Pregabalin in fibromyalgia - responder analysis from individual patient data. BMC Musculoskeletal Disorders 2010;11:150. [DOI: 10.1186/1471-2474-11-150]

\section{Sultan 2008}

Sultan A, Gaskell H, Derry S, Moore RA. Duloxetine for painful diabetic neuropathy and fibromyalgia pain: systematic review of randomised trials. BMC Neurology 2008;8:29. [DOI: 10.1186/1471-2377-8-29]

\section{Toth 2009}

Toth C, Lander J, Wiebe S. The prevalence and impact of chronic pain with neuropathic pain symptoms in the general population. Pain Medicine 2009;10(5):918-29. [DOI: 10.1111/ j.1526-4637.2009.00655.x]

\section{Watson 1998}

Watson CP, Vernich L, Chipman M, Reed K. Nortriptyline versus amitriptyline in postherpetic neuralgia: a randomized trial. Neurology 1998;51(4):1166-71.

\section{Yawn 2009}

Yawn BP, Wollan PC, Weingarten TN, Watson JC, Hooten WM, Melton LJ. The prevalence of neuropathic pain: clinical 
evaluation compared with screening tools in a community population. Pain Medicine 2009;10(3):586-93. [DOI: 10.1111/ j.1526-4637.2009.00588.x]

\section{References to other published versions of this review}

Derry 2009

Derry S, Lloyd R, Moore RA, McQuay H. Topical capsaicin

for chronic neuropathic pain in adults. Cochrane

\section{CHARACTERISTICS OF STUDIES}

Characteristics of included studies [ordered by study ID]

\section{Bernstein 1989}

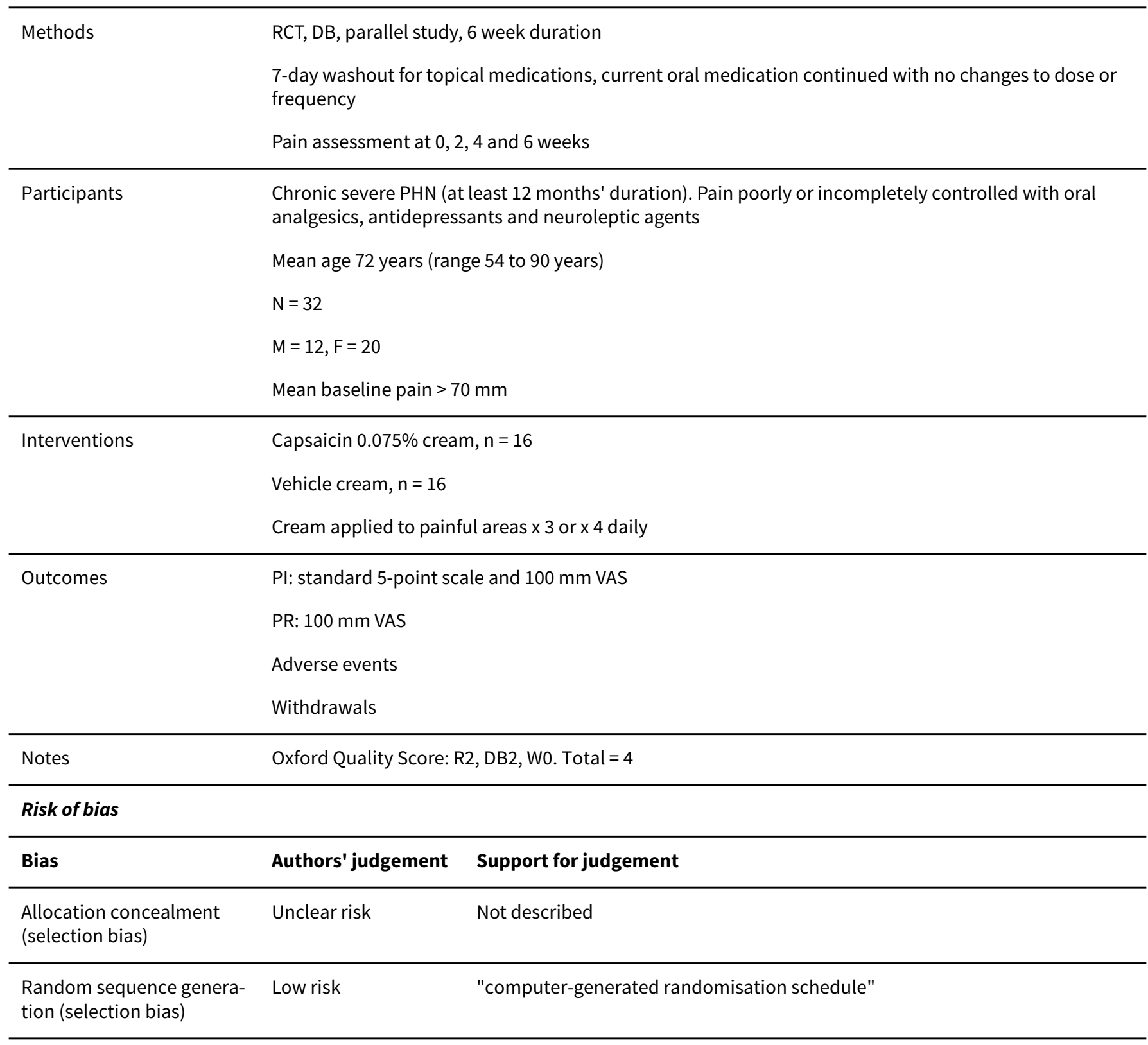

Database of Systematic Reviews 2009, Issue 4. [DOI: 10.1002/14651858.CD007393.pub2]

* Indicates the major publication for the study 
Bernstein 1989 (Continued)

Blinding of participants Low risk Active and control were identical in appearance and personnel (performance bias)

All outcomes

\begin{tabular}{lll}
\hline $\begin{array}{l}\text { Blinding of outcome as- } \\
\text { sessment (detection bias) } \\
\text { All outcomes }\end{array}$ & Low risk & Active and control were identical in appearance \\
\hline $\begin{array}{l}\text { Incomplete outcome data } \\
\text { (attrition bias) } \\
\text { All outcomes }\end{array}$ & Low risk & $3 / 32$ participants lost to follow-up, included as non-responders for analysis \\
\hline Size & High risk & Fewer than 50 participants/treatment arm \\
\hline
\end{tabular}

Biesbroeck 1995

$\begin{array}{ll}\text { Methods } & \text { RCT, DB, parallel study, } 8 \text { week duration } \\ \text { 7-day washout for all topical medication and tricyclic antidepressants. Other long-term oral therapy }\end{array}$
permitted with no changes to dose or frequency

Pain assessment at 0, 2, 4, 6 and 8 weeks

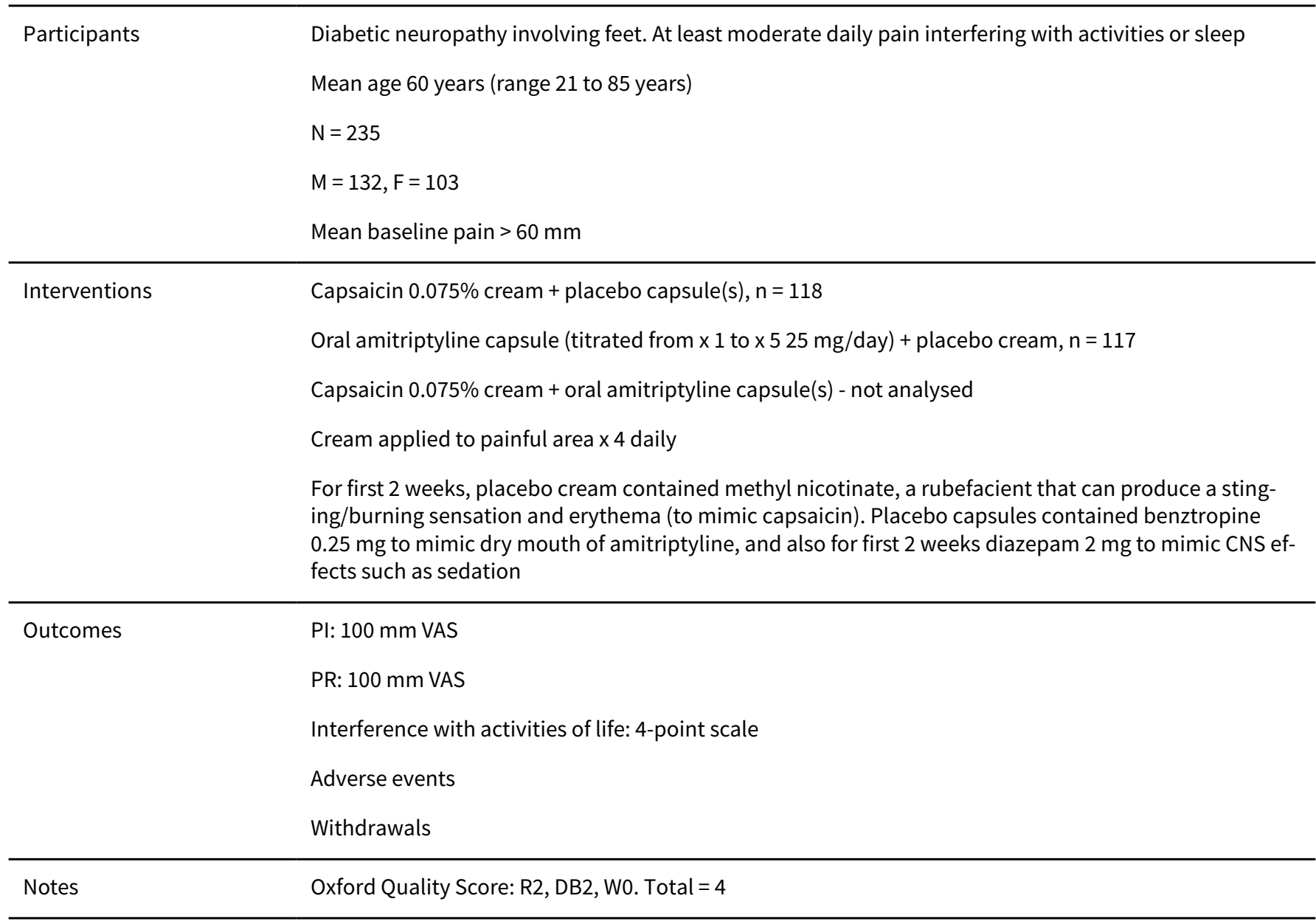


Biesbroeck 1995 (Continued)

Risk of bias

\begin{tabular}{|c|c|c|}
\hline Bias & Authors' judgement & Support for judgement \\
\hline $\begin{array}{l}\text { Allocation concealment } \\
\text { (selection bias) }\end{array}$ & Unclear risk & Not described \\
\hline $\begin{array}{l}\text { Random sequence genera- } \\
\text { tion (selection bias) }\end{array}$ & Low risk & "Computer generated randomisation schedule" \\
\hline $\begin{array}{l}\text { Blinding of participants } \\
\text { and personnel (perfor- } \\
\text { mance bias) } \\
\text { All outcomes }\end{array}$ & Low risk & Double-dummy method \\
\hline $\begin{array}{l}\text { Blinding of outcome as- } \\
\text { sessment (detection bias) } \\
\text { All outcomes }\end{array}$ & Unclear risk & Double-dummy method. Attempt to control for unmasking by adverse effects \\
\hline $\begin{array}{l}\text { Incomplete outcome data } \\
\text { (attrition bias) } \\
\text { All outcomes }\end{array}$ & Low risk & $\begin{array}{l}\text { LOCF analysis for efficacy, but no data suitable for analysis. ITT analysis for ad- } \\
\text { verse events }\end{array}$ \\
\hline Size & Unclear risk & 50 to 200 participants/treatment arm \\
\hline
\end{tabular}

\section{CSG 1992}

RCT, DB, multicentre, parallel groups, 8 week duration
7-day washout for topical medication. Oral medication continued without change. No new medication
Pain assessment at 2, 4, 6 and 8 weeks

\section{Participants}

Peripheral polyneuropathy or radiculopathy, or both, with at least moderate pain that was unresponsive or intolerant to conventional therapy and interfering with functional activities, sleep, or both

$\mathrm{N}=277$

$M=139, F=138$

Mean age 60 years (range 27 to 92 years)

Baseline pain $78 \%$ severe or very severe

\begin{tabular}{ll}
\hline Interventions & Capsaicin $0.075 \%$ cream, $\mathrm{n}=138$ \\
& Vehicle cream, $\mathrm{n}=139$ \\
& Cream applied $\mathrm{x} 4$ daily \\
\hline Outcomes & $\mathrm{Pl}: 100$ mm VAS \\
& Interference with activities of life: 4-point scale \\
& Adverse events \\
& Withdrawals \\
\hline Notes & Oxford Quality Score: R1, DB1, W1. Total = 3 \\
\hline
\end{tabular}


CSG 1992 (Continued)

Additional data for pain relief for 22 participants in Tandan 1992

\section{Risk of bias}

\begin{tabular}{|c|c|c|}
\hline Bias & Authors' judgement & Support for judgement \\
\hline $\begin{array}{l}\text { Allocation concealment } \\
\text { (selection bias) }\end{array}$ & Unclear risk & Not described \\
\hline $\begin{array}{l}\text { Random sequence genera- } \\
\text { tion (selection bias) }\end{array}$ & Unclear risk & Not described \\
\hline $\begin{array}{l}\text { Blinding of participants } \\
\text { and personnel (perfor- } \\
\text { mance bias) } \\
\text { All outcomes }\end{array}$ & Unclear risk & Not described \\
\hline $\begin{array}{l}\text { Blinding of outcome as- } \\
\text { sessment (detection bias) } \\
\text { All outcomes }\end{array}$ & Unclear risk & Not described \\
\hline $\begin{array}{l}\text { Incomplete outcome data } \\
\text { (attrition bias) } \\
\text { All outcomes }\end{array}$ & Unclear risk & $\begin{array}{l}\text { Multicentre study appears to use a completer analysis, but study does not con- } \\
\text { tribute to primary efficacy outcome }\end{array}$ \\
\hline Size & Unclear risk & 50 to 200 participants/treatment arm \\
\hline
\end{tabular}

Ellison 1997

\begin{tabular}{|c|c|}
\hline Methods & $\begin{array}{l}\text { RCT, DB, two-arm cross-over study. Only first 8-week period used in this review } \\
\text { 7-day washout for topical medication. Stable ( } \geq 10 \text { days) oral analgesic medication continued without } \\
\text { change } \\
\text { Pain assessment weekly through questionnaires and at 2-week intervals by study nurses for 8-week } \\
\text { treatment phase }\end{array}$ \\
\hline Participants & $\begin{array}{l}\text { Post-surgical neuropathic pain of } \geq \text { moderate severity and } \geq 3 \text { months' duration } \\
N=99 \\
M=27, F=72 \\
\text { Mean age } 64 \text { years } \\
\text { Median baseline pain } 60 \mathrm{~mm}\end{array}$ \\
\hline Interventions & $\begin{array}{l}\text { Capsaicin } 0.075 \% \text { cream, } n=49 \\
\text { Placebo cream, } n=50\end{array}$ \\
\hline Outcomes & $\begin{array}{l}\text { PI: } 100 \mathrm{~mm} \text { VAS } \\
\text { PR: } 100 \mathrm{~mm} \text { VAS } \\
\text { Interference with activities of life: 4-point scale } \\
\text { Adverse events }\end{array}$ \\
\hline
\end{tabular}


Ellison 1997 (Continued)

Notes Oxford Quality Score: R1, DB2, W1. Total = 4

\section{Risk of bias}

\begin{tabular}{lll}
\hline Bias & Authors' judgement & Support for judgement \\
\hline $\begin{array}{l}\text { Allocation concealment } \\
\text { (selection bias) }\end{array}$ & Unclear risk & Not described \\
\hline
\end{tabular}

Random sequence genera- Unclear risk Not described

tion (selection bias)

Blinding of participants Low risk "identical appearing placebo cream"
and personnel (perfor-
mance bias)
All outcomes

Blinding of outcome as- Low risk $\quad$ "identical appearing placebo cream"
sessment (detection bias)
All outcomes

\begin{tabular}{lll}
\hline $\begin{array}{l}\text { Incomplete outcome data } \\
\text { (attrition bias) } \\
\text { All outcomes }\end{array}$ & Low risk & BOCF analysis \\
\hline Size & High risk & Fewer than 50 participants/treatment arm \\
\hline
\end{tabular}

Low 1995

Methods DB, parallel groups, 12 week duration (8-week DB then 4-week SB placebo treatment)
Randomisation by side (left vs right). Each participant treated one leg with capsaicin and the other with
placebo
No details of washout or concomitant medication
Pain assessment at 4,8 and 12 weeks

\begin{tabular}{|c|c|}
\hline \multirow[t]{5}{*}{ Participants } & $\begin{array}{l}\text { Bilateral symmetric painful polyneuropathy involving distal lower extremities, of } \geq 6 \text { months' duration } \\
\text { and refractory to at least one other form of treatment }\end{array}$ \\
\hline & $N=40$ \\
\hline & $M=24, F=16$ \\
\hline & Mean age 59 years ( 30 to 78 ) \\
\hline & Median baseline pain $>80 \mathrm{~mm}$ \\
\hline
\end{tabular}

Placebo (contained methyl nicotinate), $n=40$

Cream applied $x 4$ daily

First tube of placebo contained methyl nicotinate, a rubefacient that can produce a stinging/burning sensation and erythema (to mimic capsaicin) 
Low 1995 (Continued)

\begin{tabular}{ll} 
Outcomes & PI: $10 \mathrm{~cm}$ VAS \\
& PR: $10 \mathrm{~cm}$ VAS and 7-point scale \\
& Interference with activities of life: 4-point scale \\
& Adverse events \\
\hline Notes & Oxford Quality Score: R1, DB2, W1. Total = 4
\end{tabular}

\section{Risk of bias}

\begin{tabular}{|c|c|c|}
\hline Bias & Authors' judgement & Support for judgement \\
\hline $\begin{array}{l}\text { Allocation concealment } \\
\text { (selection bias) }\end{array}$ & Unclear risk & Not described \\
\hline $\begin{array}{l}\text { Random sequence genera- } \\
\text { tion (selection bias) }\end{array}$ & Unclear risk & Not described \\
\hline $\begin{array}{l}\text { Blinding of participants } \\
\text { and personnel (perfor- } \\
\text { mance bias) } \\
\text { All outcomes }\end{array}$ & Low risk & "tubes of identical appearance" \\
\hline $\begin{array}{l}\text { Blinding of outcome as- } \\
\text { sessment (detection bias) } \\
\text { All outcomes }\end{array}$ & Low risk & "tubes of identical appearance" \\
\hline $\begin{array}{l}\text { Incomplete outcome data } \\
\text { (attrition bias) } \\
\text { All outcomes }\end{array}$ & Low risk & $39 / 40$ participants completed \\
\hline Size & High risk & Fewer than 50 participants/treatment arm \\
\hline
\end{tabular}

Watson 1992

$\begin{array}{ll}\text { Methods } & \text { RCT, DB, parallel group, } 6 \text { week duration } \\ \text { 7-day washout for topical agents, and no new oral agents permitted during the trial } \\ \text { Pain assessment at baseline and weekly intervals, and with daily pain diaries }\end{array}$

Interventions

Capsaicin $0.075 \%$ cream, $n=14$

Vehicle cream, $\mathrm{n}=11$ 
Watson 1992 (Continued)

Cream applied $x 4$ daily

PI: $10 \mathrm{~cm}$ VAS and 4-point scale
PR: $10 \mathrm{~cm}$ VAS and percentage improvement
Patient global evaluation: 4-point scale
Interference with activities of life: 4-point scale
Adverse events
Withdrawals

Notes Oxford Quality Score: R1, DB1, W1. Total = 3

\section{Risk of bias}

\begin{tabular}{lll}
\hline Bias & Authors' judgement & Support for judgement \\
\hline $\begin{array}{l}\text { Allocation concealment } \\
\text { (selection bias) }\end{array}$ & Unclear risk & Not described \\
\hline $\begin{array}{l}\text { Random sequence genera- } \\
\text { tion (selection bias) }\end{array}$ & Unclear risk & Not described \\
\hline $\begin{array}{l}\text { Blinding of participants } \\
\text { and personnel (perfor- } \\
\text { mance bias) }\end{array}$ & Unclear risk & Not described \\
$\begin{array}{l}\text { All outcomes } \\
\text { Blinding of outcome as- } \\
\text { sessment (detection bias) } \\
\text { All outcomes }\end{array}$ & High risk & Not described, but "compromised by burning sensation" \\
\hline $\begin{array}{l}\text { Incomplete outcome data } \\
\text { (attrition bias) } \\
\text { All outcomes }\end{array}$ & Low risk & All participants accounted for \\
\hline \begin{tabular}{l} 
Size \\
\hline
\end{tabular} & High risk & Fewer than 50 participants/treatment arm \\
\hline
\end{tabular}

\section{Watson 1993}

Methods $\quad$ RCT, DB, parallel group, 6 week duration

7-day washout for topical medication. Oral medication continued without change. No new medication

Pain assessment at 0, 2, 4 and 6 weeks

\section{Participants}

Chronic post-herpetic neuralgia of at least 6 months' duration, with pain poorly or incompletely controlled with oral analgesic, antidepressants or neuroleptic agents in most participants

$$
\begin{aligned}
& N=143 \\
& M=53, F=90 \\
& \text { Mean age } 71 \text { years } \\
& \text { Baseline pain } 90 \% \text { moderate or severe, } 10 \% \text { very severe }
\end{aligned}
$$


Watson 1993 (Continued)

\begin{tabular}{ll} 
Interventions & Capsaicin $0.075 \%$ cream, $\mathrm{n}=74$ \\
& Vehicle cream, $\mathrm{n}=69$ \\
& Cream applied $\mathrm{x} 4$ daily \\
\hline Outcomes & PI: 100 mm VAS and 5-point scale \\
& PR: 100 mm VAS \\
& Functional capacity: 5-point scale \\
& Adverse events \\
Withdrawals
\end{tabular}

Notes Oxford Quality Score: R2, DB2, W0. Total = 4

\section{Risk of bias}

\begin{tabular}{|c|c|c|}
\hline Bias & Authors' judgement & Support for judgement \\
\hline $\begin{array}{l}\text { Allocation concealment } \\
\text { (selection bias) }\end{array}$ & Unclear risk & Not described \\
\hline $\begin{array}{l}\text { Random sequence genera- } \\
\text { tion (selection bias) }\end{array}$ & Low risk & "computer generated" \\
\hline $\begin{array}{l}\text { Blinding of participants } \\
\text { and personnel (perfor- } \\
\text { mance bias) } \\
\text { All outcomes }\end{array}$ & Low risk & "identical appearance" \\
\hline $\begin{array}{l}\text { Blinding of outcome as- } \\
\text { sessment (detection bias) } \\
\text { All outcomes }\end{array}$ & Low risk & "identical appearance" \\
\hline $\begin{array}{l}\text { Incomplete outcome data } \\
\text { (attrition bias) } \\
\text { All outcomes }\end{array}$ & Unclear risk & All participants accounted for, but group not specified for exclusions \\
\hline Size & Unclear risk & 50 to 200 participants/treatment arm \\
\hline
\end{tabular}

BOCF: baseline observation carried forward; CNS: central nervous system; DB: double blind; F: female; ITT: intention to treat; LOCF: last observation carried forward; M: male; N: number of participants in study; n: number of participants in treatment arm; PHN: postherpetic neuralgia; PI:- pain intensity; PR: pain relief; R: randomised; RCT: randomised controlled trial; SB: single blind; VAS: visual analogue scale; W: withdrawals.

Characteristics of excluded studies [ordered by study ID]

\begin{tabular}{ll}
\hline Study & Reason for exclusion \\
\hline Chad 1990 & Study only 4 weeks' duration \\
\hline Fusco 1992 & Too few patients (12 total), open label \\
\hline McCarty 1994 & Study only 4 weeks' duration \\
\hline
\end{tabular}




\begin{tabular}{|c|c|}
\hline Study & Reason for exclusion \\
\hline McCleane 2000 & Study only 4 weeks' duration \\
\hline Paice 2000 & Study only 4 weeks' duration \\
\hline Peikert 1991 & Not an RCT \\
\hline Pfeifer 1993 & Not an RCT \\
\hline Robbins 1998 & Not an RCT, too few participants (10 total) \\
\hline Vickers 1998 & Not an RCT \\
\hline Watson 1988 & Not an RCT \\
\hline Watson 1989 & Not an RCT \\
\hline
\end{tabular}

$\mathrm{RCT}$ : randomised controlled trial.

Characteristics of ongoing studies [ordered by study ID]

\section{NCT00993070}

\section{Trial name or title}

Methods

Participants

Interventions

Interventions

Capsaicin gel $0.025 \%$ applied $4 \mathrm{x}$ daily

Placebo (vehicle) gel, applied $4 \mathrm{x}$ daily for 8 weeks

\section{Outcomes}

Pain relief, using VAS and neuropathic pain scale

Safety and tolerability

\begin{tabular}{ll}
\hline Starting date & October 2009, estimated completion June 2012 \\
\hline Contact information & Pl: Kongkiat Kulkantrakokrn, Thammasat University, Thailand \\
\hline Notes & Estimated enrolment: 40 \\
\hline
\end{tabular}

RCT: randomised controlled trial; VAS: visual analogue scale.

\section{DATA AND ANALYSES}

\section{Comparison 1. Capsaicin $0.075 \%$ versus placebo}

\begin{tabular}{lllll}
\hline Outcome or subgroup title & No. of studies & $\begin{array}{l}\text { No. of partici- } \\
\text { pants }\end{array}$ & Statistical method & Effect size \\
\hline 1 Clinical improvement & 5 & & Risk Ratio (M-H, Fixed, 95\% Cl) & Totals not selected \\
\hline
\end{tabular}




\begin{tabular}{|c|c|c|c|c|}
\hline Outcome or subgroup title & No. of studies & $\begin{array}{l}\text { No. of partici- } \\
\text { pants }\end{array}$ & Statistical method & Effect size \\
\hline $1.1 \geq 50 \%$ pain relief & 2 & & Risk Ratio (M-H, Fixed, 95\% Cl) & $0.0[0.0,0.0]$ \\
\hline $\begin{array}{l}1.2 \text { Unspecified or }<50 \% \text { pain re- } \\
\text { lief }\end{array}$ & 3 & & Risk Ratio (M-H, Fixed, 95\% Cl) & $0.0[0.0,0.0]$ \\
\hline $\begin{array}{l}2 \text { Adverse event: burning, sting- } \\
\text { ing, erythema }\end{array}$ & 5 & 557 & Risk Ratio (M-H, Fixed, 95\% Cl) & $2.64[2.10,3.31]$ \\
\hline $\begin{array}{l}3 \text { Adverse event: coughing, } \\
\text { sneezing }\end{array}$ & 5 & 557 & Risk Ratio (M-H, Fixed, 95\% Cl) & $5.73[2.15,15.25]$ \\
\hline 4 Adverse event withdrawal & 4 & 477 & Risk Ratio (M-H, Fixed, 95\% Cl) & $5.02[2.28,11.08]$ \\
\hline
\end{tabular}

\section{Analysis 1.1. Comparison 1 Capsaicin $0.075 \%$ versus placebo, Outcome 1 Clinical improvement.}

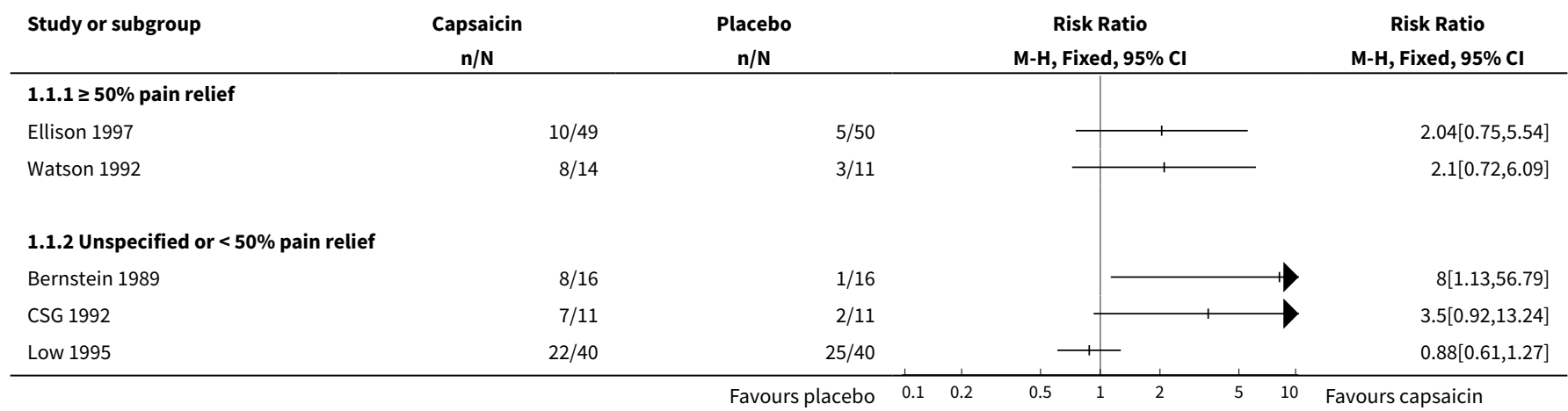

Analysis 1.2. Comparison 1 Capsaicin $0.075 \%$ versus placebo, Outcome 2 Adverse event: burning, stinging, erythema.

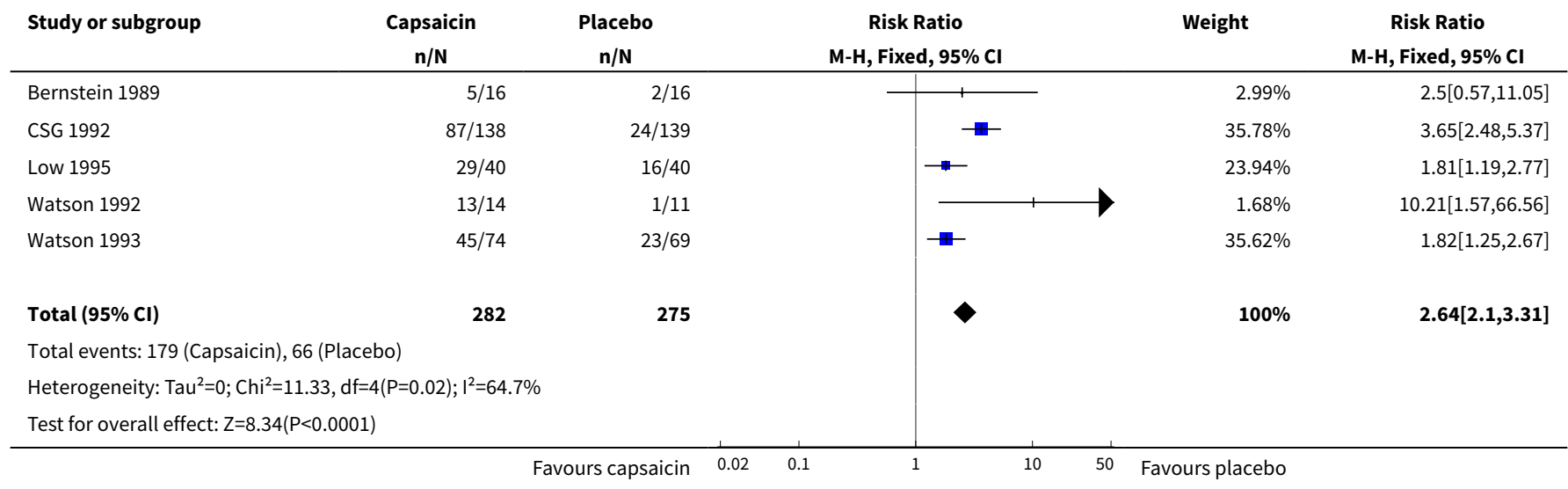


Analysis 1.3. Comparison 1 Capsaicin $0.075 \%$ versus placebo, Outcome 3 Adverse event: coughing, sneezing.

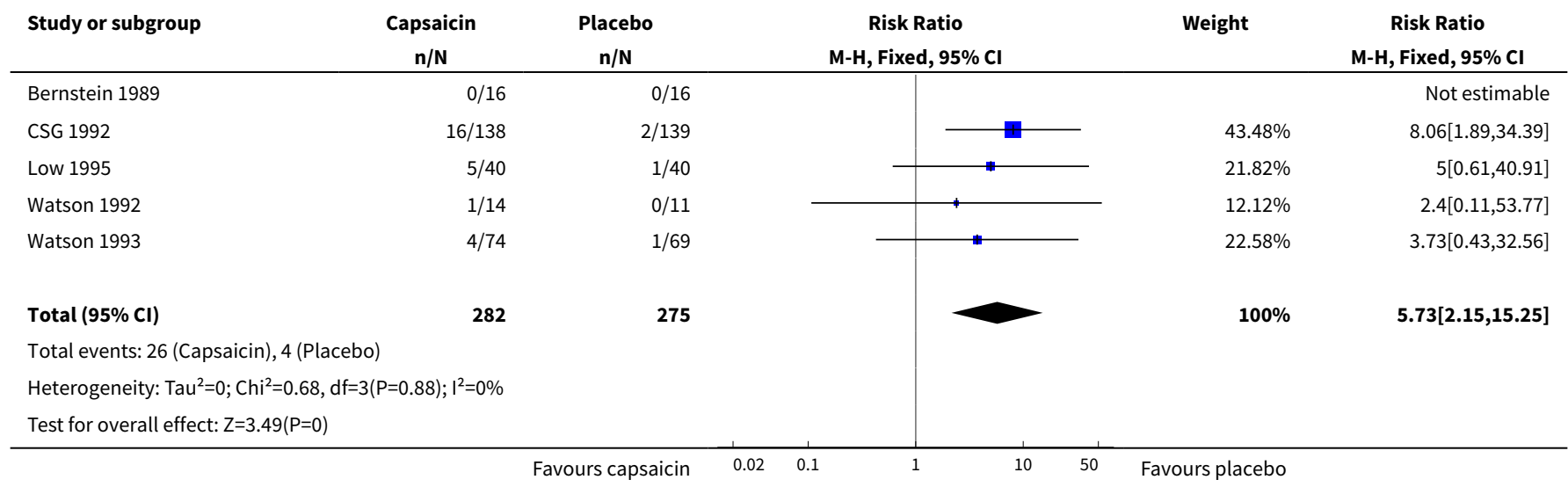

\section{Analysis 1.4. Comparison 1 Capsaicin $0.075 \%$ versus placebo, Outcome 4 Adverse event withdrawal.}

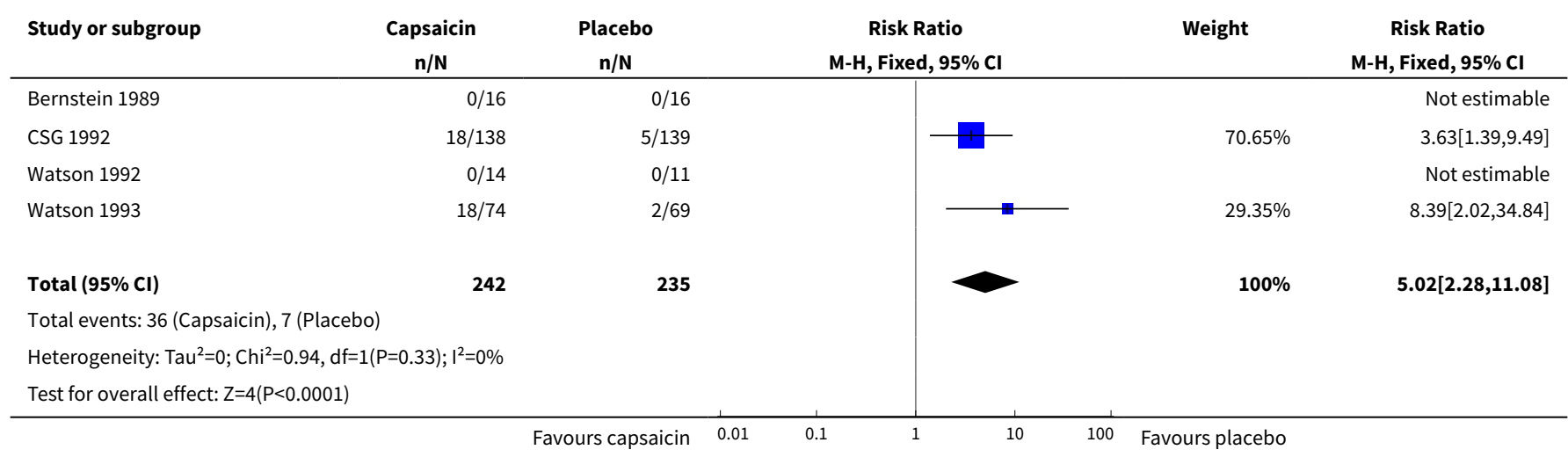

\section{APPENDICES}

\section{Appendix 1. MEDLINE search strategy (via Ovid)}

1. Capsaicin.sh

2. (capsaicin $O R$ capsaicine $O R$ capsici $O R$ axsain $O R$ capsidol OR capsig OR capsin OR capsina OR capsiplast OR capzasin-P OR dolorac OR gelcen OR katrum OR "No pain-HP" OR priltam OR "R-gel" OR zacin OR zostrix OR capsicum).ti,ab,kw

3. $1 \mathrm{OR} 2$

4. exp Administration, topical.sh

5. (topical\$ OR cutaneous OR dermal OR transcutaneous OR transdermal OR percutaneous OR skin OR massage OR embrocation OR gel $O R$ ointment $O R$ aerosol $O R$ cream $O R$ crème $O R$ lotion $O R$ foam $O R$ liniment $O R$ spray $O R$ rub $O R$ balm $O R$ salve $O R$ emulsion $O R$ oil OR patch OR plaster).ti,ab,kw

6. 4 OR 5

7. Diabetic neuropathies.sh OR Peripheral neuropathies.sh OR Polyneuropathies.sh OR Neuralgia.sh

8. (neuropath\$ OR diabet\$ post-herpetic OR neuralgia).ti,ab,kw

9. 7 OR 8

10.(pain OR painful OR analgesi\$).ti,ab,kw

11.randomized controlled trial.pt

12.controlled clinical trial.pt 
13.randomized.ab

14. placebo.ab

15.drug therapy.fs

16.randomly.ab

17.trial.ab

18.groups.ab

19. OR/11-18

20.3 AND 6 AND 9 AND 19

\section{Appendix 2. EMBASE search strategy (via Ovid)}

1. Capsaicin.sh

2. (capsaicin OR capsaicine OR capsici OR axsain OR capsidol OR capsig OR capsin OR capsina OR capsiplast OR capzasin-P OR dolorac OR gelcen OR katrum OR "No pain-HP" OR priltam OR "R-gel" OR zacin OR zostrix OR capsicum).ti,ab,kw

3. 1 OR 2

4. exp Topical Drug Administration.sh

5. (topical\$ OR cutaneous OR dermal OR transcutaneous OR transdermal OR percutaneous OR skin OR massage OR embrocation OR gel OR ointment OR aerosol OR cream OR crème OR lotion OR foam OR liniment OR spray OR rub OR balm OR salve OR emulsion OR oil OR patch OR plaster).ti,ab,kw

6. 4 OR 5

7. Diabetic Neuropathy.sh OR Peripheral neuropathy.sh OR Polyneuropathy.sh OR Neuralgia.sh

8. (neuropath\$ OR diabet\$ post-herpetic OR neuralgia).ti,ab,kw

9. 7 OR 8

10.(pain OR painful OR analgesi\$).ti,ab,kw

11.clinical trials.sh

12.controlled clinical trials.sh

13.randomized controlled trial.sh

14.double-blind procedure.sh

15. (clin\$ adj25 trial\$).ab

16. ((doubl\$ or trebl\$ or tripl\$) adj25 (blind\$ or mask\$)).ab

17. placebo\$.ab

18.random\$.ab

19.0R/11-18

20.3 AND 6 AND 9 AND 10 AND 19

\section{Appendix 3. CENTRAL search strategy}

1. MESH descriptor Capsaicin

2. (capsaicin OR capsaicine OR capsici OR axsain OR capsidol OR capsig OR capsin OR capsina OR capsiplast OR capzasin-P OR dolorac OR gelcen OR katrum OR "No pain-HP" OR priltam OR "R-gel" OR zacin OR zostrix OR capsicum):ti,ab,kw

3. 1 OR 2

4. exp MESH descriptor Administration, topical

5. (topical ${ }^{\star}$ OR cutaneous OR dermal OR transcutaneous OR transdermal OR percutaneous OR skin OR massage OR embrocation OR gel OR ointment OR aerosol OR cream OR crème OR lotion OR foam OR liniment OR spray OR rub OR balm OR salve OR emulsion OR oil OR patch OR plaster):ti,ab,kw

6. 4 OR 5

7. MESH descriptor (Diabetic neuropathies OR Peripheral neuropathies OR Polyneuropathies OR Neuralgia)

8. (neuropath* OR diabet* post-herpetic OR neuralgia):ti,ab,kw

9. 7 OR 8

10. (pain OR painful OR analgesi ${ }^{\star}$ ):ti,ab,kw

11.Randomized Controlled Trial:pt.

12.MESH descriptor Double-Blind Method

13. (double or treble or triple) NEXT (blind* or mask*)):ti,ab,kw.

14. random*:ti,ab,kw.

15.OR/11-14 
16.3 AND 6 AND 9 AND 10 AND 15

17. Limit 16 to Clinical Trials (CENTRAL)

Appendix 4. Summary of outcomes in individual studies: efficacy

\begin{tabular}{lll}
\hline Study ID & Treatment & Clinical improvement \\
\hline Bernstein 1989 & (1) Capsaicin $0.075 \%$ cream, $n=16$ & $\geq 40 \%$ pain relief at 6 weeks: \\
& (2) Vehicle cream, $n=16$ & (1) $8 / 16$ \\
\hline Biesbroeck 1995 & (1) Capsaicin $0.075 \%$ cream, $n=118$ & (2) $1 / 16$ \\
\hline & (2) Amitriptyline 25 to $125 \mathrm{mg}$ (oral), $n=117$ & Mean decrease in pain intensity at 8 weeks: \\
& & (1) $42 \%$ \\
\hline
\end{tabular}

CSG 1992 (1) Capsaicin $0.075 \%$ cream, $n=138 \quad$ Mean decrease in pain intensity at 8 weeks:

$\begin{array}{ll}\text { (2) Vehicle cream, } n=139 & \text { (1) } 40.1 \%\end{array}$

(2) $27.8 \%$

\begin{tabular}{ll}
\hline Ellison 1997 & $\geq 75 \%$ decrease in pain score: \\
(2) Capsaicin $0.075 \%$ cream, $n=49$ & (1) $10 / 49$ \\
& (2) $5 / 50$
\end{tabular}

\begin{tabular}{ll}
\hline Low 1995 & Undefined improvement at 8 weeks: \\
$\begin{array}{ll}\text { (2) Placebo cream, } n=40 & \text { (1) } 22 / 40 \\
& \text { (2) } 25 / 40\end{array}$
\end{tabular}

\begin{tabular}{ll}
\hline Tandan 1992 (part of & (1) Capsaicin $0.075 \%$ cream, $n=11$ \\
CSG 1992) & (2) Placebo cream, $n=11$
\end{tabular}

(2) Placebo cream, $n=11$

Reduction in pain by at least one category at 8 weeks:
(1) $7 / 11$
(2) $2 / 11$

\begin{tabular}{ll}
\hline Watson 1992 & (1) Capsaicin 0.075\% cream, $n=14$ \\
& (2) Vehicle cream, $n=11$
\end{tabular}

$\geq 50 \%$ pain relief at 6 weeks:

(2) Vehicle cream, $n=11$

(1) $8 / 14$

(2) $3 / 11$

\begin{tabular}{ll}
\hline Watson 1993 & Mean decre \\
$\begin{array}{ll}\text { (1) Capsaicin } 0.075 \% \text { cream, } n=74 & \text { (1) } 20.9 \%\end{array}$ \\
$\begin{array}{ll}\text { (2) Vehicle cream, } n=69 & \text { (2) } 5.8 \%\end{array}$
\end{tabular}

\section{Appendix 5. Summary of outcomes in individual studies: adverse events and withdrawals}




\begin{tabular}{|c|c|c|c|c|c|}
\hline Study ID & Treatment & Local AEs & Systemic AEs & Serious AEs & Withdrawals/exclusions \\
\hline $\begin{array}{l}\text { Bernstein } \\
1989\end{array}$ & $\begin{array}{l}\text { (1) Capsaicin } \\
0.075 \% \text { cream, } n= \\
16 \\
\text { (2) Vehicle cream, } \\
n=16\end{array}$ & $\begin{array}{l}\text { Burning, stinging, ery- } \\
\text { thema } \\
\text { (1) } 5 / 16 \\
\text { (2) } 2 / 16\end{array}$ & None & None & $\begin{array}{l}\text { AE: none } \\
\text { Other: } \\
3 \text { lost to follow-up - no details } \\
\text { of group or time }\end{array}$ \\
\hline
\end{tabular}

\begin{tabular}{|c|c|c|c|c|c|}
\hline $\begin{array}{l}\text { Biesbroeck } \\
1995\end{array}$ & $\begin{array}{l}\text { (1) Capsaicin } \\
0.075 \% \text { cream, } n= \\
118 \\
\text { (2) Amitripty- } \\
\text { line } 25 \text { to } 125 \mathrm{mg} \\
\text { (oral), } \mathrm{n}=117\end{array}$ & $\begin{array}{l}\text { Total skin AEs: } \\
\text { (1) } 68 / 118 \text { ( } 52 \text { burning) } \\
\text { (2) } 2 / 117 \text { (unspecified) } \\
\text { Cough/sneeze: } \\
\text { (1) } 7 / 118 \\
\text { (2) } 1 / 117\end{array}$ & $\begin{array}{l}\text { None with } \\
\text { capsaicin } \\
\text { Limited ther- } \\
\text { apeutic dose } \\
\text { for majority of } \\
\text { amitriptyline } \\
\text { participants }\end{array}$ & $\begin{array}{l}\text { (1) None } \\
\text { (2) Not report- } \\
\text { ed }\end{array}$ & $\begin{array}{l}\text { AE: none related to capsaicin } \\
\text { Other: } \\
\text { (1) } 14 \text { did not contribute any } \\
\text { post baseline efficacy data } \\
\text { (2) } 9 \text { did not contribute any } \\
\text { post baseline efficacy data }\end{array}$ \\
\hline
\end{tabular}

\begin{tabular}{|c|c|c|c|c|c|}
\hline \multirow[t]{3}{*}{ CSG 1992} & $\begin{array}{l}\text { (1) Capsaicin } \\
0.075 \% \text { cream, } n= \\
138\end{array}$ & $\begin{array}{l}\text { Burning: } \\
\text { (1) } 87 / 138\end{array}$ & $\begin{array}{l}\text { Other AE: } \\
\text { (1) } 6 / 138\end{array}$ & No data & $\begin{array}{l}\text { AE: } \\
\text { (1) } 18 / 138\end{array}$ \\
\hline & (2) Vehicle cream, & (2) $17 / 139$ & (2) $8 / 139$ & & (2) $5 / 139$ \\
\hline & $\mathrm{n}=139$ & Cough/sneeze: & $\begin{array}{l}\text { Increased } \\
\text { pain: }\end{array}$ & & Other: \\
\hline
\end{tabular}
(1) $16 / 138$
(1) $2 / 138$
(2) $2 / 139$
(2) $5 / 139$

Burning, cough, sneeze, rash, erythema:

(1) 113 events

(1) 20/138 (7 non-compliant, 10 other health problems, 3 other)

(2) $15 / 139$ (6 non-compliant, 2 lack of efficacy, 5 other health problems, 2 other)

(2) 29 events

\begin{tabular}{llll}
\hline Ellison 1997 & $\begin{array}{l}\text { (1) Capsaicin } \\
0.075 \% \text { cream, } n=\end{array}$ & $\begin{array}{l}\text { Significantly more } \\
\text { burning, redness and } \\
\text { coughing with cap- } \\
\text { saicin than placebo }(\mathrm{P}<\end{array}$ & No data \\
$\begin{array}{ll}\text { (2) Placebo cream, } \\
\mathrm{n}=50\end{array}$ & No data \\
& $\begin{array}{l}\text { Data from both phases } \\
\text { combined }\end{array}$ &
\end{tabular}

\begin{tabular}{|c|c|c|c|c|c|}
\hline Low 1995 & $\begin{array}{l}\text { (1) Capsaicin } \\
0.075 \% \text { cream, } n= \\
40 \\
\text { (2) Placebo cream, } \\
n=40\end{array}$ & $\begin{array}{l}\text { Burning: } \\
\text { (1) } 29 / 40 \\
\text { (2) } 16 / 40 \\
\text { Sneezing: } \\
\text { (1) } 5 / 40 \\
\text { (2) } 1 / 40 \\
\text { Itching: } \\
\text { (1) } 4 / 40 \\
\text { (2) } 2 / 40\end{array}$ & No data & No data & $\begin{array}{l}\text { One did not complete entire } \\
\text { study - no further details }\end{array}$ \\
\hline
\end{tabular}


(Continued)

Rash:

(1) $5 / 40$

(2) $0 / 40$

\begin{tabular}{|c|c|c|c|c|c|}
\hline Watson 1992 & $\begin{array}{l}\text { (1) Capsaicin } \\
0.075 \% \text { cream, } n= \\
14 \\
\text { (2) Vehicle cream, } \\
n=11\end{array}$ & $\begin{array}{l}\text { Burning: } \\
\text { (1) } 13 / 14 \\
\text { (2) } 1 / 11 \\
\text { Cough: } \\
\text { (1) } 1 / 14 \\
\text { (2) } 0 / 11\end{array}$ & No data & No data & $\begin{array}{l}\text { AE: } \\
\text { (1) } 1 / 14 \\
\text { (2) } 0 / 11 \\
\text { Other: } \\
\text { (1) } 0 / 14 \\
\text { (2) } 1 / 11 \text { (recurrence of malig- } \\
\text { nancy) }\end{array}$ \\
\hline Watson 1993 & $\begin{array}{l}\text { (1) Capsaicin } \\
0.075 \% \text { cream, } n= \\
74 \\
\text { (2) Vehicle cream, } \\
n=69\end{array}$ & $\begin{array}{l}\text { Burning, stinging, ery- } \\
\text { thema: } \\
\text { (1) } 45 / 74 \\
\text { (2) } 23 / 69 \\
\text { Cough: } \\
\text { (1) } 4 / 74 \\
\text { (2) } 1 / 69\end{array}$ & $\begin{array}{l}\text { No more than } \\
\text { 3/group with } \\
\text { any systemic } \\
\text { AE. No signif- } \\
\text { icant differ- } \\
\text { ence between } \\
\text { groups }\end{array}$ & None & $\begin{array}{l}\text { AE: } \\
\text { (1) } 18 / 74 \\
\text { (1) } 2 / 69 \\
\text { Other: } \\
\text { (1) } 2 / 74 \\
\text { (2) } 1 / 69 \\
\text { Exclusions: } 12 \text { participants } \\
\text { treated did not meet entrance } \\
\text { criteria, further } 6 \text { had protocol } \\
\text { violations }\end{array}$ \\
\hline
\end{tabular}

AE: adverse event.

WHAT'S NEW

\begin{tabular}{lll}
\hline Date & Event & Description \\
\hline 29 May 2019 & Amended & Contact details updated. \\
\hline 8 March 2016 & Review declared as stable & See Published notes. \\
\hline
\end{tabular}

\section{H ISTORY}

Review first published: Issue 9, 2012

\begin{tabular}{lll}
\hline Date & Event & Description \\
\hline 11 July 2014 & Review declared as stable & This review will be assessed for updating in 2017. \\
\hline 24 April 2012 & $\begin{array}{l}\text { New citation required and conclusions } \\
\text { have changed }\end{array}$ & $\begin{array}{l}\text { Original review split according to concentration of capsaicin in } \\
\text { the product; this review considers low concentration }(<1 \%) \text { cap- }\end{array}$ \\
\hline
\end{tabular}




\begin{tabular}{lll}
\hline Date Event Description & Den
\end{tabular}

saicin, while another review considers high concentration (8\%) capsaicin. New searches were carried out and no new studies identified. We re-analysed the data to take account of revised guidelines for systematic reviews in pain, which resulted in efficacy estimates being downgraded; there were insufficient data to draw any reliable conclusions about efficacy in neuropathic pain. Conclusions about harm were unchanged.

\section{CONTRIBUTIONS OFAUTHORS}

For the original review SD and RL carried out searches for studies, data extraction and analyses. RAM was involved with analysis and HJM acted as arbitrator. All authors were involved with writing the review.

For the update SD carried out searches and both SD and RAM revised the text. SD will be responsible for the update of this review.

\section{DECLARATIONS OF INTEREST}

RAM and SD have received research support from charities, government and industry sources at various times. RAM has consulted for various pharmaceutical companies and received lecture fees from pharmaceutical companies related to analgesics and other healthcare interventions. No pharmaceutical company had any involvement with this review.

\section{SOURCES OF SUPPORT}

\section{Internal sources}

- Oxford Pain Relief Trust, UK.

- Pain, Palliative and Supportive Care Group, UK.

\section{External sources}

- No sources of support supplied

\section{DIFFERENCES BETWEEN PROTOCOLANDREVIEW}

For this update we have used recently revised guidelines for reviews in pain, which take into account our better understanding of potential biases both in studies and in the review process (AUREF 2012).

\section{NOTES}

A restricted search in March 2016 identified a small number of potentially relevant studies (data from 77 participants), none of which reported a benefit for low dose capsaicin over placebo, or unexpected adverse events that could change the conclusions. Therefore, this review has not been updated but has now been stabilised following discussion with the authors and editors. The review will be re-assessed for updating if new evidence likely to change the conclusions is published, or if standards change substantially which necessitate major revisions. This review is part of our UK NIHR Cochrane Programme Grant: 13/89/29 - Addressing the unmet need of chronic pain: providing the evidence for treatments of pain.

\section{IN DEX TERMS}

\section{Medical Subject Headings (MeSH)}

Administration, Topical; Capsaicin [ ${ }^{\star}$ administration \& dosage] [adverse effects]; Chronic Pain [ ${ }^{\star}$ drug therapy]; Drug Administration Schedule; Neuralgia [*drug therapy]; Randomized Controlled Trials as Topic; Sensory System Agents [ ${ }^{\star}$ administration \& dosage] [adverse effects]

\section{MeSH check words}

Adult; Humans 